DOE/RL-2009-18

Revision 0

\title{
2009 Evaluation of Tritium Removal and Mitigation Technologies for Wastewater Treatment
}

Prepared for the U.S. Department of Energy

Assistant Secretary for Environmental Management

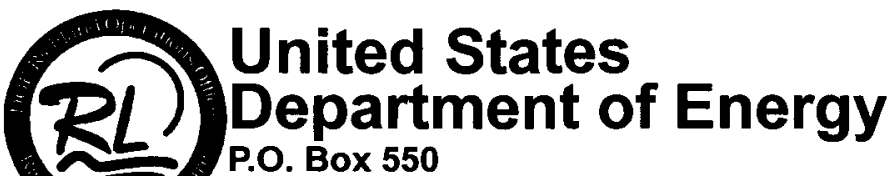

Richland, Washington 99352

Àpproved for Públic Release;

Further Dissemination Unlimited 


\section{Evaluation of Tritium Removal and Mitigation Technologies for Wastewater Treatment}

D. J. Geniesse

G. E. Stegen AREVA

Date Published

February 2009

Prepared for the U.S. Department of Energy

Assistant Secretary for Environmental Management

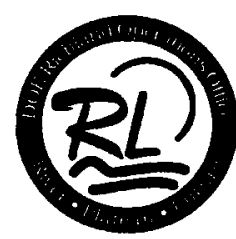

\section{United States}

Department of Energy

P.O. Box 550

Richland, Washington 99352

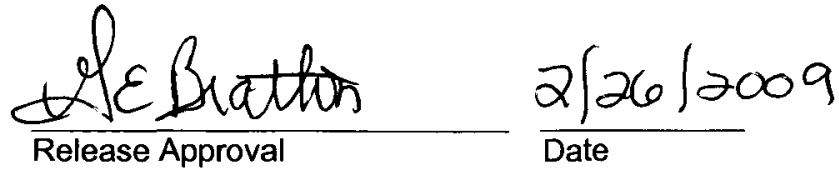

Approved for Public Rejease;

Further Dissemination Unlimited 
DOE/RL-2009-18

Revision 0

TRADEMARK DISCLAIMER

Reference herein to any specific commercial product, process, or service by trade name, trademark, manufacturer, or otherwise, does not necessarily constitute or imply its endorsement, recommendation, or favoring by the United States Government or any agency thereof or its contractors or subcontractors.

This report has been reproduced from the best available copy. Available in paper copy. 


\begin{abstract}
Since 1995, a state-approved land disposal site (SALDS) has received tritium contaminated effluents from the Hanford Site Effluent Treatment Facility (ETF). Tritium in this effluent is mitigated by storage in slow moving groundwater to allow extended time for decay before the water reaches the site boundary. By this method, tritium in the SALDS is isolated from the general environment and human contact until it has decayed to acceptable levels.
\end{abstract}

This report contains the 2009 update evaluation of alternative tritium mitigation techniques to control tritium in liquid effluents and groundwater at the Hanford site. A thorough literature review was completed and updated information is provided on state-of-the-art technologies for control of tritium in wastewaters. This report was prepared to satisfy the Hanford Federal Facility Agreement and Consent Order (Tri-Party Agreement) Milestone M-026-07B (Ecology, EPA, and DOE 2007). Tritium separation and isolation technologies are evaluated periodically to determine their feasibility for implementation to control Hanford site liquid effluents and groundwaters to meet the U.S. Code of Federal Regulations (CFR), Title 40 CFR 141.16, drinking water maximum contaminant level (MCL) for tritium of 20,000 $\rho \mathrm{Ci} / \mathrm{L}$ and/or DOE Order 5400.5 as low as reasonably achievable (ALARA) policy.

Since the 2004 evaluation, there have been a number of developments related to tritium separation and control with potential application in mitigating tritium contaminated wastewater. These are primarily focused in the areas of 1) tritium recycling at a commercial facility in Cardiff, UK using integrated tritium separation technologies (water distillation, palladium membrane reactor, liquid phase catalytic exchange, thermal diffusion), 2) development and demonstration of Combined Electrolysis Catalytic Exchange (CECE) using hydrogen/water exchange to separate tritium from water, 3) evaporation of tritium contaminated water for dispersion in the atmosphere, and 4) use of barriers to minimize the transport of tritium in groundwater.

Continuing development efforts for tritium separations processes are primarily to support the International Thermonuclear Experimental Reactor (ITER) program, the nuclear power industry, and the production of radiochemicals. While these applications are significantly 
different than the Hanford application, the technology could potentially be adapted for Hanford wastewater treatment.

Separations based processes to reduce tritium levels below the drinking water MCL have not been demonstrated for the scale and conditions required for treating Hanford wastewater. In addition, available cost information indicates treatment costs for such processes will be substantially higher than for discharge to SALDS or other typical pump and treat projects at Hanford. Actual mitigation projects for groundwater with very low tritium contamination similar to that found at Hanford have focused mainly on controlling migration and on evaporation for dispersion in the atmosphere. 


\section{TABLE OF CONTENTS}

ABSTRACT. .. V

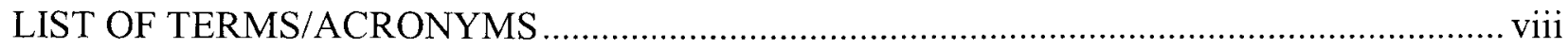

SCIENTIFIC ABBREVIATIONS AND CONVERSIONS .............................................. ix

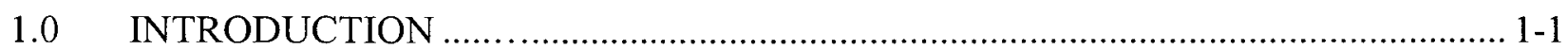

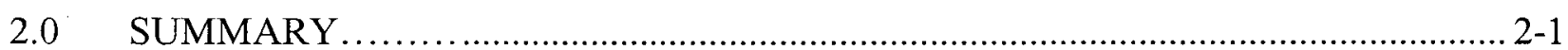

3.0 REMOVAL AND MITIGATION TECHNOLOGIES FOR TRITIUM ...................... 3-1 IN WASTEWATERS

3.1 INDUSTRIAL HYDROGEN-ISOTOPE SEPARATION ............................... 3-1 TECHNOLOGIES

3.1.1 Water Distillation...................................................................... 3-1

3.1.2 Combined Electrolysis Catalytic Exchange........................................... 3-4

3.1.3 Bithermal Hydrogen-Water Process ...................................................... 3-9

3.1.4 Girdler Sulfide Process ................................................................... 3-10

3.1.5 Palladium Membrane Reactor........................................................... 3-13

3.1.6 GE Integrated Systems............................................................ 3-14

3.1.7 Other Industrial Hydrogen Isotope Separation Processes................... 3-16

3.2 DEVELOPMENTAL HYDROGEN-ISOTOPE SEPARATIONS .................. 3-17 TECHNOLOGIES

3.2.1 Tritium Sorbent Process.............................................................. 3-17

3.2.2 Other Developmental Processes ..................................................... 3-17

3.3 OTHER TRITIUM MITIGATION TECHNOLOGIES FOR …..................... 3-17 WASTEWATERS

3.3.1 Pump and Recharge ....................................................................... 3-17

3.3.2 Barrier Formation....................................................................... 3-18

3.3.3 Decay in Slow Moving Groundwater ........................................... 3-20

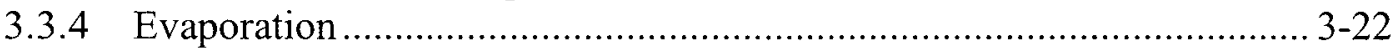

3.4 RELATIVE COST OF MITIGATION OPTIONS .................................. 3-25

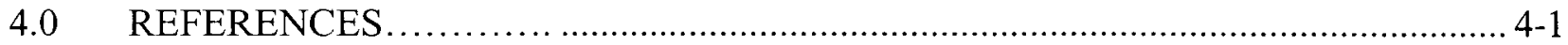




\section{FIGURES}

Figure 1. Estimated Hanford Tritium Inventory ....................................................... 1-1

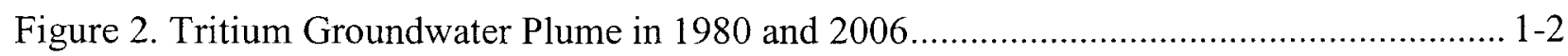

Figure 3. Water Distillation - Theoretical Plates Versus Reflux Ratio............................... 3-2

Figure 4. Combined Electrolysis Catalytic Exchange Process ....................................... 3-7

Figure 5. Bithermal Hydrogen-Water Process ....................................................... 3-11

\section{TABLES}

Table 1. Column Sizing and Power Rough Estimate Assumptions .................................... 3-3

Table 2. MSI Tritium Decay Versus Storage Time ...................................................... 3-20

Table 3. Tritiated Water Discharges to the State-Approved Land Disposal Site ................. 3-21

Table 4. Sources of Tritiated Water to SALDS ............................................................ 3-22

Table 5. Maximum Tritium Concentrations and Depth to Water at Hanford........................ 3-25

Table 6. Comparison of Mitigation Approaches........................................................ 3-27 


\section{LIST OF TERMS/ACRONYMS}

\begin{tabular}{|c|c|}
\hline AECL & Atomic Energy of Canada, Limited \\
\hline BLIP & Brookhaven Linear Accelerator Isotope Producer \\
\hline BNL & Brookhaven National Laboratory \\
\hline CECE & Combined Electrolysis Catalytic Exchange \\
\hline CFR & United States Code of Federal Regulations \\
\hline CIRCE & Combined Industrial Reforming and Catalytic Exchange \\
\hline Deprotinate & To remove light water $\left(\mathrm{H}_{2} \mathrm{O}\right)$ from heavy water $\left(\mathrm{D}_{2} \mathrm{O}\right)$ \\
\hline Deuterium (D) & An isotope of hydrogen with one proton and one neutron \\
\hline DF & Decontamination Factor \\
\hline DOE & U. S. Department of Energy \\
\hline DWS & Drinking Water Standard \\
\hline EPRI & Electric Power Research Institute \\
\hline ETF & Effluent Treatment Facility \\
\hline GE & GE-Hitachi Nuclear Energy \\
\hline GS & Girdler Sulfide \\
\hline Heavy water & Water that contains two deuterium atoms and one oxygen atom \\
\hline HETP & Height Equivalent of a Theoretical Plate \\
\hline ITER & International Thermonuclear Experimental Reactor \\
\hline JET & Joint European Torus \\
\hline LERF & Liquid Effluent Retention Facility \\
\hline MCL & Maximum contaminant level \\
\hline MVR & Mechanical Vapor Recompression \\
\hline NTP & Number of Theoretical Plates \\
\hline Phytoremediation & Remediation using plants to perform the remediation \\
\hline Protium & Ordinary hydrogen - the nucleus contains only a proton \\
\hline PMR & Palladium Membrane Reactor \\
\hline SALDS & State-Approved Land Disposal Site \\
\hline SRS & Savannah River Site \\
\hline $\mathrm{T} / \mathrm{D}$ & Tritium/Deuterium \\
\hline $\mathrm{T} / \mathrm{H}$ & Tritium/Hydrogen \\
\hline Tri-Party Agreement & Hanford Federal Facility Agreement and Consent Order \\
\hline Tritium (T) & $\begin{array}{l}\text { A radioactive isotope of hydrogen - the nucleus contains one proton and } 2 \\
\text { neutrons. Tritium has a half life of } 12.3 \text { years. }\end{array}$ \\
\hline Tritiated Water & Water that contains at least one tritium atom \\
\hline UK & United Kingdom \\
\hline VLB & Viscous Liquid Barrier \\
\hline
\end{tabular}




\section{SCIENTIFIC ABBREVIATIONS AND CONVERSIONS}

\section{Units of Measure}

$\underline{\text { Unit }}$

${ }^{\circ} \mathrm{C}$

$\mathrm{Ci}$

$\mathrm{cm}$

$\mu \mathrm{Ci}$

$\mu \mathrm{Ci} / \mathrm{L}$

$\mu \mathrm{Ci} / \mathrm{mL}$

gal

$\mathrm{gal} / \mathrm{yr}$

gpm

hectare

${ }^{\circ} \mathrm{K}$

$\mathrm{kA}$

$\mathrm{kg}$

$\mathrm{km}$

$\mathrm{kWh}$

L

$\mathrm{L} / \mathrm{s}$

$\mathrm{L} / \mathrm{h}$

$\mathrm{m}$

$\mathrm{mL}$

$\mathrm{mL} / \mathrm{min}$

$\mathrm{mm}$

mrem

$\rho \mathrm{Ci}$

$\rho \mathrm{Ci} / \mathrm{L}$

\section{Definition}

degrees centigrade

curie $=3.7 \times 10^{10}$ Becquerel $(\mathrm{Bq})$

Centimeter

microcurie $\quad\left(10^{-6}\right.$ curie $)$

microcuries per liter

microcuries per milliliter

gallon

gallons per year

gallons per minute

$10,000 \mathrm{~m}^{2}$

degrees Kelvin (absolute temperature)

kiloamps

kilograms

kilometer

kilowatt hour

liter

Liters per second

Liters per hour

meter

milliliter

milliliters per minute

millimeter $\quad\left(10^{-3}\right.$ meter $)$

milliroentgen equivalent man

picocurie $\quad\left(10^{-12}\right.$ curie $)$

picocuries per liter 


\section{Elements and Compounds}

Hydrogen Isotopes

$\mathrm{H}\left({ }^{1} \mathrm{H}\right)$ protium

$\mathrm{D}\left({ }^{2} \mathrm{H}\right)$ deuterium

$\mathrm{T}\left({ }^{3} \mathrm{H}\right)$ tritium
Atomic Mass

1.008

2.014

3.017

Pure tritium with a mass of 1.03 grams is equivalent to $10,000 \mathrm{Ci}$

$\mathrm{D}_{2}$

$\mathrm{D}_{2} \mathrm{O}$

DT

DTO

$\mathrm{H}_{2}$

$\mathrm{H}_{2} \mathrm{O}$

HD

HDO

HT

HTO, $\mathrm{T}_{2} \mathrm{O}$

$\mathrm{T}_{2}$

\section{Abbreviations}

g

1

$\mathrm{Kd}$

$\mathrm{p}\left(\mathrm{H}_{2} \mathrm{O}\right)$

$\mathrm{p}$ (HTO) deuterium molecule

deuterium oxide (heavy water)

tritiated deuterium

tritiated deuterium oxide

hydrogen molecule

water (light water-protium oxide or protinated water)

deuterated hydrogen

deuterated water

tritiated hydrogen

tritiated water

tritium molecule

gas

liquid

distribution coefficient

partial pressure of $\mathrm{H}_{2} \mathrm{O}$

partial pressure of HTO 


\subsection{INTRODUCTION}

Tritium (T) was generated as a by-product in reactor fuel at the Hanford site by the U.S. Defense Program in nuclear reactor operations from 1944 to 1989 . Tritium is typically in the form of tritiated water (mainly $\mathrm{HTO}$ and rarely $\mathrm{T}_{2} \mathrm{O}$ ), and decays with a half life of 12.3 years producing helium. Figure 1 illustrates cumulative production and decay of tritium from the Hanford Site based on data from (Roblyer 1994).

Figure 1. Estimated Hanford Tritium Production and Decay

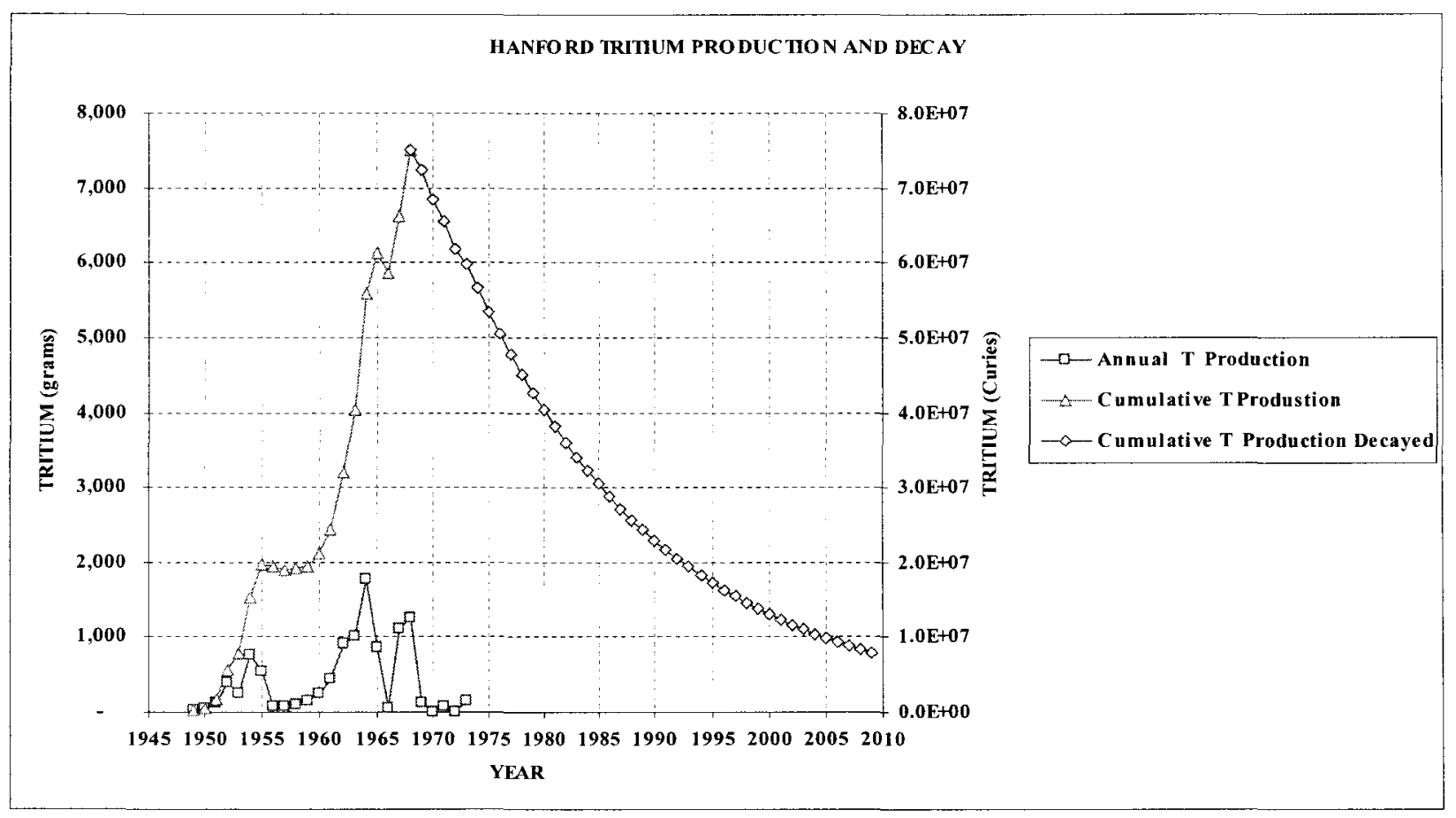

Significant tritium inventories remain in Hanford Site groundwater and in underground waste storage tanks (Jeppson et al. 1997). The bulk of the tritiated water from fuel reprocessing facilities was released to the soil column in 200 Area in-process condensates. Prior to 1995, 1.6 trillion liters ( 440 billion gallons) of contaminated process water were discharged into the soil column (Jeppson 1994). Groundwater monitoring in the 200-East Area measured levels exceeding $4 \times 10^{6} \rho \mathrm{Ci} / \mathrm{L}$.

Tritium in previously discharged liquid effluents has migrated into the groundwater, and in some cases, toward and into the Columbia River. Atmospheric and ground releases of tritium from the Hanford site were about $40 \mathrm{Ci}$ in 1992 (Woodruff and Hanf 1993). Subsurface migration of tritium-containing groundwater into the Columbia River was estimated to be 4,600 Ci for 1992 (Knepp 1994). Figure 2 shows the extent of the tritium groundwater plume in 1980 and 2006 (Hartman 2007). Concentrations of tritium in Hanford groundwater continues to decline as a result of natural decay and dispersion. 
Figure 2. Tritium Groundwater Plume in 1980 and 2007 (Hartman 2007)
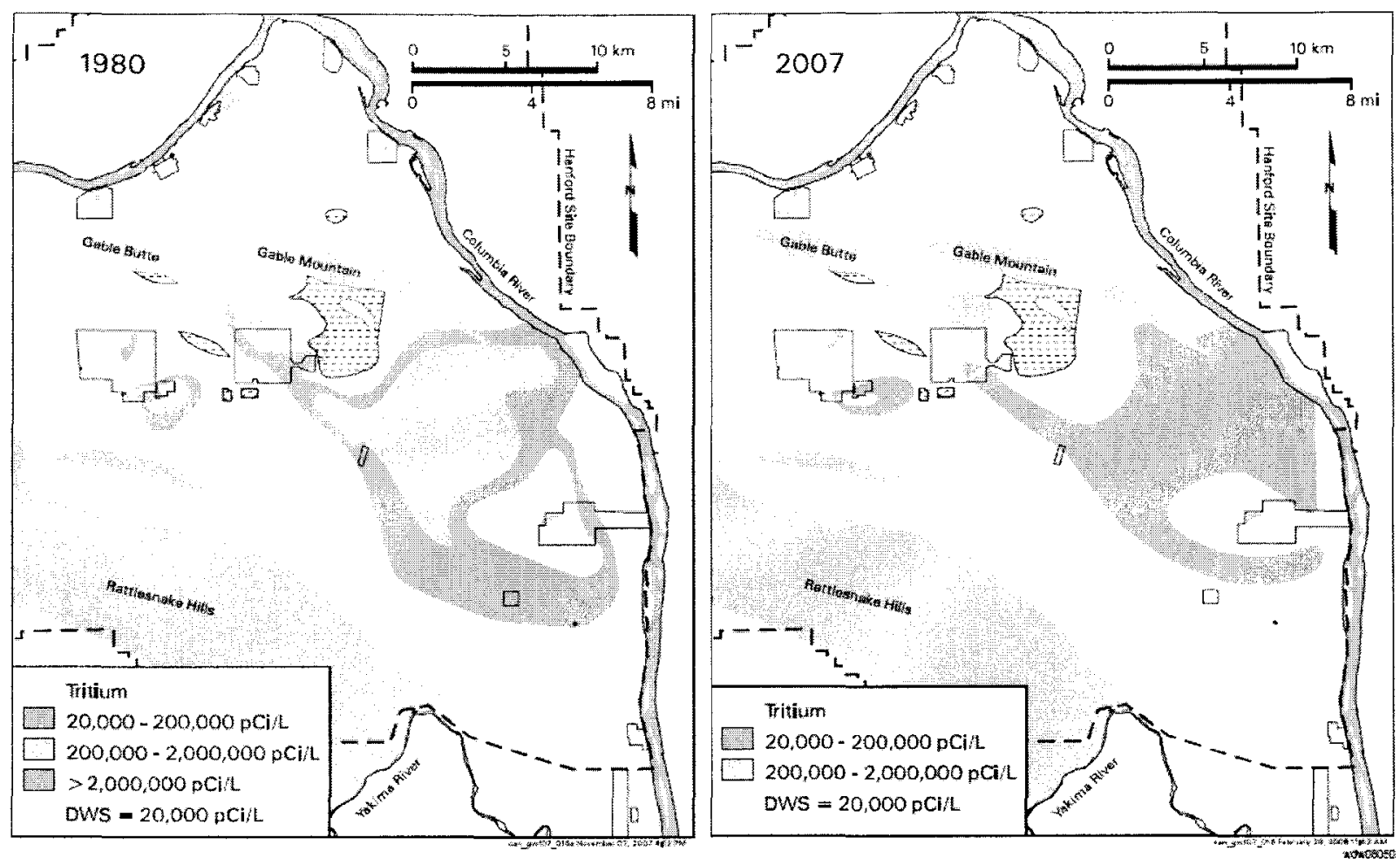

Monitoring of Columbia River water in 2007 measured a background tritium concentration at the Priest Rapids Dam of $48 \rho \mathrm{Ci} / \mathrm{L}$ and a level of $114 \rho \mathrm{Ci} / \mathrm{L}$ at the Richland pumphouse (Bisping 2007), indicating an increase of $66 \rho \mathrm{Ci} / \mathrm{L}$ through the Hanford site. The increase is likely due from migration of groundwater from the 200-East Area from past operations. At the highest level $(136 \rho \mathrm{Ci} / \mathrm{L})$, the Columbia River contains less than $0.6 \%$ of the $20,000 \rho \mathrm{Ci} / \mathrm{L}$ drinking water standard for tritium (DWS40 - CFR 141.16).

Since 1995, a state-approved land disposal site (SALDS) has received effluents from the Hanford site Effluent Treatment Facility (ETF) that are essentially free of all contaminants except tritium. The majority of tritium discharged to the SALDS during the period 2005 to 2008 came from the $\mathrm{K}$ Basin wastewater, 242-A Evaporator condensate, and treated groundwater streams.

Releases to the ground have greatly decreased since the last fuel was processed through the fuel separations plant in 1989. The total quantity of tritium discharged to the SALDS during August and September 2007 as well as FY08 was $10 \mathrm{Ci}$. (Caron 2008). During this period, 75.15 million L (19.85 million gallons) of water were discharged from ETF to SALDS. Thus, the averaged concentration of discharged tritium in FY08 was $133,000 \rho \mathrm{Ci} / \mathrm{L}\left(1.38 \times 10^{-11} \mathrm{~g} / \mathrm{L}\right)$. From December 1995 to July 2008, 878 million liters (232 million gallons) were discharged containing $412.5 \mathrm{Ci}$, for an overall average of $470,000 \rho \mathrm{Ci} / \mathrm{L}$. Maximum groundwater tritium concentrations measured in 2008 from SALDS proximal monitoring wells was $820,000 \rho \mathrm{Ci} / \mathrm{L}$ (Caron 2008). This concentration spike was likely caused by processing K Basin wastewater 
through the ETF; typical tritium concentrations at SALDS proximal wells are less than 100,000 $\rho \mathrm{Ci} / \mathrm{L}$.

Discharge to SALDS allows natural radioactive decay to substantially reduce tritium content before the wastewater enters the Columbia River. Computer modeling results predict a relatively long travel time (many times the half life) for tritium bearing effluents discharged to SALDS to reach the Columbia River. The models indicate that tritium from the SALDS disposal site will not reach the Columbia River in detectable quantities (Ecology 2000).

In 1991, the U.S. Department of Energy, Richland Operations Office (Site Technology Coordination Group [STCG]), issued a notice of the need to reduce tritium concentrations in Hanford site wastewaters from 2-3 million $\rho \mathrm{Ci} / \mathrm{L}$ to less than $20,000 \rho \mathrm{Ci} / \mathrm{L}$ (RL-MW023, Technology Needs/Opportunities Statement [HST 1991]). A Hanford site Fiscal Year 1999 Waste Tank Science Need, RL-WT047-S (RL 1999), was issued that called for identification of viable processes for reducing tritium concentrations in Hanford site wastewaters.

The concentration of tritium in ETF outfall to the SALDS decreased to an average of $133,000 \rho \mathrm{Ci} / \mathrm{L}$ in FY08 due to natural decay and lower concentration sources. At the natural decay rate, the average concentration of tritium in wastewater discharged in 2008 will decrease to the DWS in 33 years. During this period, groundwater from the SALDS will not migrate from the Hanford site. Earlier evaluations (Penwell 2001) assumed that tritium cleanup processes would need a decontamination factor (DF) of about 100 (i.e. product water tritium concentration $=1 / 100$ times the wastewater feed concentration). Tritium concentrations in wastewater discharged to SALDS fluctuate drastically over time (see Section 3.3.3), and long term forecasts for future discharges are not currently available. Based on discharges during the past five years, it appears that a DF of 100 is a reasonable target value and is used for the current evaluation.

Since 1996, the annual volume of water discharged to SALDS has varied between about five and 28 million gallons per year. For the current evaluation, it is assumed a nominal 100 gallon per minute (gpm) feed capacity is sufficient for wastewater treatment processes. This is sufficient to handle the historical maximum annual discharge, but could require some feed lag storage to handle maximum short term discharges from ETF.

The current report is one in a series concerning tritium mitigation technologies. DOE/RL-94-77 (Allen 1994) provided an initial evaluation of tritium treatment and disposal options. Periodic updates on status of tritium mitigation technology have been published since that time:

DOE/RL-95-68 (Allen 1995), DOE/RL-97-54, Rev. 0 (Jeppson et al. 1997), DOE/RL-9942, Rev. 0 (Jeppson 1999), DOE/RL-2001-33, Rev. 0 (Penwell 2001), and DOE/RL-2004-11 (Klem 2004). The current report provides an update of developments in the area of tritium mitigation technology since the 2004 update. The earlier reports should be consulted for additional background information that is not repeated herein. 


\subsection{SUMMARY}

Since 1995, a state-approved land disposal site (SALDS) has received tritium contaminated effluents from the Hanford Site Effluent Treatment Facility (ETF). Tritium in this effluent is mitigated by storage in slow moving groundwater to allow extended time for decay before the water reaches the site boundary. By this method, tritium in the SALDS is isolated from the general environment and human contact until it has decayed to acceptable levels.

Separations based processes to reduce tritium levels below the drinking water MCL have not been demonstrated for the scale and conditions required for treating Hanford wastewater. In addition previous evaluations showed that available cost data indicates treatment costs for such processes will be substantially higher than for discharge to SALDS or other typical pump and treat projects at Hanford. Current total cost for processing wastewater through the ETF is $\$ 0.58 /$ gallon (Lueck 2009). Cost for SALDS disposal is estimated to be less than $\$ 0.01 /$ gallon.

To determine if new technologies may be technically and economically feasible to reduce tritium in Hanford ETF outfall, a literature search was conducted to update information in earlier reviews. Separation processes were identified, described, and evaluated for application to ETF effluent. Other potentially applicable methods for mitigation of tritium contaminated wastewater or groundwater at the Hanford Site were also considered. Conclusions from this review are that there have been some advances in tritium separations technology, but that nothing has materially changed that would affect selection of SALDS discharge as the preferred approach for handling the ETF effluent.

The ETF outfall is characterized as a high flow ( 5 to $28 \mathrm{Mgal} / \mathrm{yr}$ ) low tritium concentration wastewater. Peak tritium concentrations of 2 to 3 million $\rho \mathrm{Ci} / \mathrm{L}$ during 2004-2008 occurred during treatment of $\mathrm{K}-\mathrm{Basin}$ water. To meet the current drinking water standard $(20,000 \rho \mathrm{Ci} / \mathrm{L}) \mathrm{a}$ nominal 100 -fold reduction $(\mathrm{DF}=100)$ in tritium concentration is required.

Currently, there are no technologies available that can selectively remove the trace amounts of tritium from the ETF outfall in a single simple step. Rather, complex multistage separations processes are required because only a small degree of tritium separation can be achieved in a single stage. Conventional heavy water production methods (distillation, Girdler Sulfide, CECE, etc.) are highly energy intensive and the high costs can not be justified for recovering a small amount of tritium from the ETF outfall.

Development work since the last update report has continued on separations processes based on water distillation, catalytic exchange of hydrogen isotopes between elemental hydrogen gas and water, the combined electrolysis and catalytic exchange (CECE), palladium metal membrane/reactor separation, gas adsorption/desorption, gaseous diffusion, and thermal diffusion. An integrated system using water distillation, palladium metal membrane separation, and thermal diffusion has been developed by GE-Hitachi Nuclear Energy (GE) and installed at a commercial site in the UK that produces radiochemicals. Additional system concepts that use gaseous diffusion and/or liquid phase catalytic exchange have also been developed by GE and are being marketed for other potential applications. These systems were developed for 
applications with relatively small liquid waste volumes compared to the subject Hanford wastewater.

Water distillation of tritiated water is the simplest separation method. It relies on the boiling point difference $\left(1.5^{\circ} \mathrm{C}\right)$ between tritiated water and ordinary water. The method is used at heavy water plants for the first crude separation. However, due to the low relative volatility $\left(\mathrm{p}\left(\mathrm{H}_{2} \mathrm{O}\right) / \mathrm{p}(\mathrm{HTO})=1.056\right)$ and the high throughput $(100 \mathrm{gpm})$, water distillation requires several hundred theoretical plates $(>200)$, a high reflux ratio $(>25)$, and multiple large diameter distillation columns $\left(>24^{\prime}\right)$. The high reflux rate makes the process approximately thirty times more energy consumptive than one-pass evaporation. Some economy may be gained by mechanical vapor recompression (MVR) of the overheat steam from the column to heat the reboiler. Even so, the capital and energy costs are prohibitively high for the Hanford application.

Similarly, the gas adsorption/desorption based processes are suitable for applications with relatively small waste volumes and relatively high tritium concentrations compared to Hanford wastewater.

Catalytic exchange technology has been developed and demonstrated primarily for applications that support the fusion reactor program and the heavy water moderated fission reactor operations, but could potentially be adapted for treating large volumes of groundwater and waste water with trace tritium contamination. However, the cost and energy consumption is expected to be relatively high.

Tests of a sorption based process have demonstrated some separation of tritium from wastewater but have not successfully demonstrated feasibility of the overall process. The process lacks large scale demonstration and available information indicates treatment costs are relatively high even if the method proves feasible.

One approach for mitigation of tritium in wastewater is to store it underground in a stagnant or slow moving aquifer where it will be isolated from the general environment and human consumption for an extended period of time. This approach has the advantages of low cost and low energy consumption provided a suitable storage location is available. This method is being used at the Hanford SALDS facility where groundwater migration rates are closely monitored to prevent environmental contamination.

Work has continued at several contaminated sites to mitigate bulk wastewater and groundwater with trace tritium contamination by implementing actions to restrict or alter groundwater movement by pumping or barriers and evaporation for air dispersion (thermal evaporation and "phytoremediation," or use of plants to uptake and evaporate groundwater). These "last ditch" efforts are not required for the Hanford SALDS facility, which provides isolation from the environment while tritium concentrations decay to relatively low levels. 
DOE/RL-2009-18

Revision 0

\subsection{REMOVAL AND MITIGATION TECHNOLOGIES FOR TRITIUM IN WASTEWATERS}

Section 3.1 discusses industrial processes for separation of hydrogen isotopes in water. Section 3.2 discusses developmental processes for separating tritium from protinated water $\left(\mathrm{H}_{2} \mathrm{O}\right)$. Other tritium mitigation methods for contaminated water are included in Section 3.3. Available information on relative costs is discussed in Section 3.4.

\subsection{INDUSTRIAL HYDROGEN-ISOTOPE SEPARATION TECHNOLOGIES}

Hydrogen isotope separation technologies include processes that separate deuterated water (HDO and $\mathrm{D}_{2} \mathrm{O}$ ) from $\mathrm{H}_{2} \mathrm{O}$ and/or tritiated water (HTO) from $\mathrm{HDO}$ and $\mathrm{D}_{2} \mathrm{O}$. None of these processes are used on a large commercial scale for separating very low concentrations of tritium from light water to meet the MCL concentration. Processes discussed in this section would require some work to be adapted to the Hanford wastewater treatment requirements, but this is considered to be a moderate extrapolation from past successful applications of the processes.

\subsubsection{Water Distillation}

Isotope separation by water distillation is based on the small differences in vapor pressure between water species containing different hydrogen isotopes. Water distillation for separation of $\mathrm{HDO}$ and $\mathrm{D}_{2} \mathrm{O}$ from $\mathrm{H}_{2} \mathrm{O}$ is a safe and well-established process that has been used on an industrial scale at commercial heavy water nuclear reactors for many years in the United States, Canada, and Europe. Typical feed rates to commercial heavy water plants are $\sim 1 \mathrm{gpm}$. Water distillation has generally not been used to remove traces of HTO from large volumes of wastewatersuch as ETF outfall (@100 gpm).

GE-Hitachi Nuclear Energy (GE) has recently implemented water distillation for tritium removal of a relatively small waste stream at a radiochemical processing facility in the United Kingdom (UK) (Bonnett 2008A, 2008B). GE has also proposed water distillation for treatment of wastewater at commercial nuclear power plants. A key feature of the GE process is use of vapor recompression to reduce energy consumption and cooling water demand. Earlier evaluations of Hanford wastewater treatment were based on a simple boiler/condenser configuration similar to what is used on heavy water upgraders. For the current evaluation, water distillation was reconsidered based on use of vapor recompression as discussed below.

\subsubsection{Process Description}

Water distillation separation is based on the relative volatility of $\mathrm{HTO}$ and $\mathrm{H}_{2} \mathrm{O}$. At $60^{\circ} \mathrm{C}$, the $\mathrm{H}_{2} \mathrm{O}$ vapor pressure is about 1.056 times that of HTO (Van Hook 1968). Thus the equilibrium liquid mole fraction of HTO is 1.056 higher than the gas phase mole fraction.

For the Hanford application a decontamination factor (DF) of about 100 is needed, so that the HTO concentration in the product needs to be reduced by $99 \%$ compared to the feed. To achieve this separation, several hundred distillation stages (theoretical plates) are required. The number of theoretical plates (NTP) varies with the reflux ratio (ratio of recycled condensate to net 
product). A higher reflux ratio is more energy intensive, but reduces the NTP. The relationship between reflux ratio and NTP required for the upper (stripping section) of the distillation column is illustrated by Figure 3.

Figure 3. Water Distillation - Theoretical Plates Versus Reflux Ratio for a DF of 100

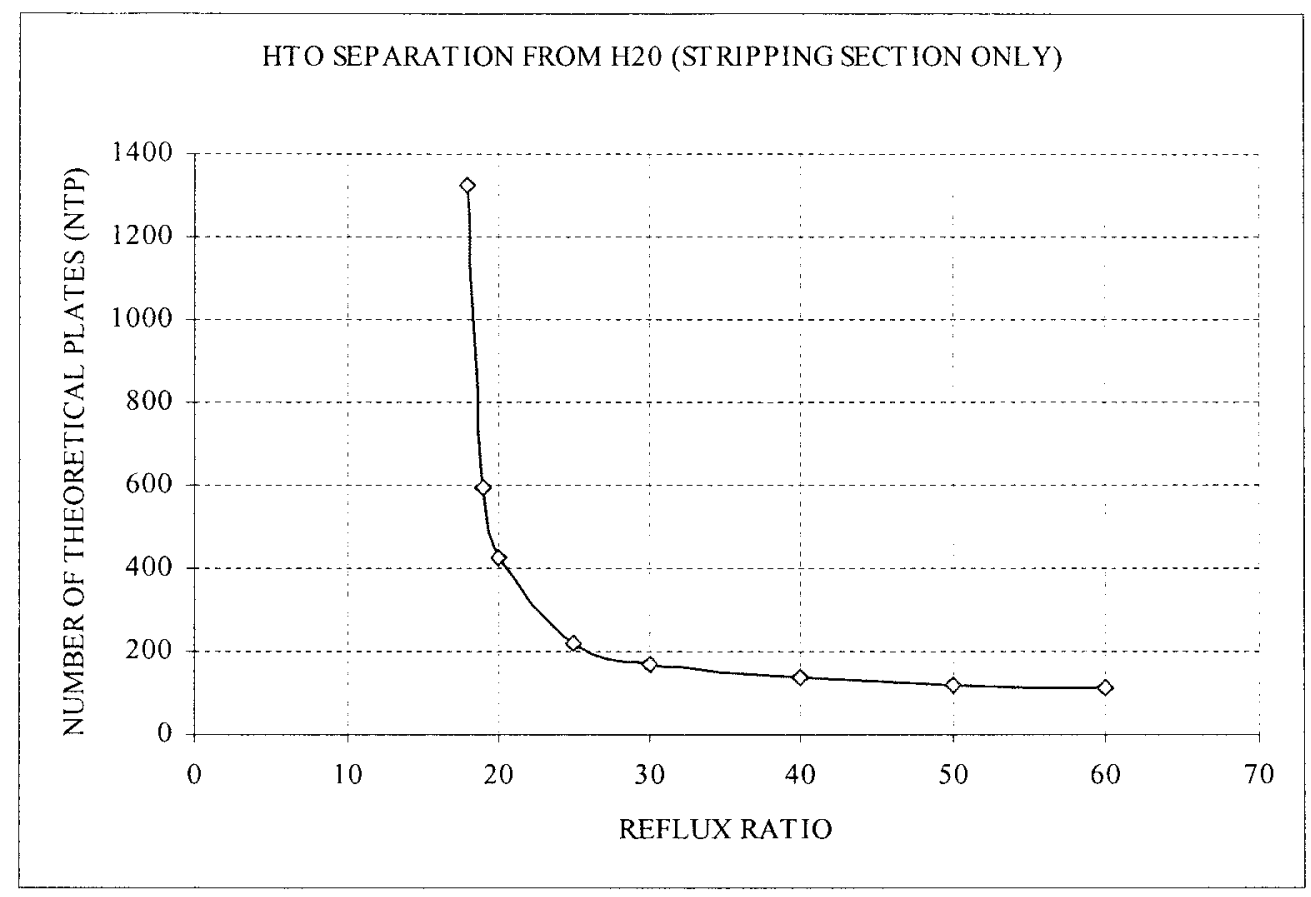

As shown by the diagram, a reflux ratio of $\sim 30$ is reasonably optimum for balancing required NTP with required reflux flow. The NTP is not reduced much as the reflux ratio increases above 30 , and the required NTP begins to increase rapidly if the reflux ratio is reduced much below 30 .

By countercurrent contacting of ascending vapor and descending liquid, tritiated water is depleted from the overhead product and enriched in the lower (rectifying) section of the column. Liquid from the column bottom flows to the reboiler. A small fraction of the water in the reboiler $(10 \%$ of the feed) is removed and sent to a second distillation column for further concentration. Two-stage distillation reduces the overall size of the equipment.

To evaluate feasibility of water distillation, a rough estimate of column sizing and power was made based on the assumptions shown in Table 1. 
Table 1. Column Sizing and Power Rough Estimate Assumptions

\begin{tabular}{|c|c|}
\hline Number of Parallel Process Trains & 10 \\
\hline Wastewater Feed Rate & $\begin{array}{l}100 \mathrm{gpm}\left(0.38 \mathrm{~m}^{3} / \mathrm{min}\right) \text { Total } \\
10 \mathrm{gpm}\left(.04 \mathrm{~m}^{3} / \mathrm{min}\right) \text { Per Train }\end{array}$ \\
\hline \multicolumn{2}{|l|}{ Primary Column Parameters } \\
\hline $\begin{array}{l}\text { Product water tritium } \\
\text { concentration }\end{array}$ & 0.001 times feed concentration \\
\hline Reboiler Concenrate & $\begin{array}{l}\text { Reboiler bottoms concentrated to } 10 \text { times feed } \\
\text { concentration, } 1 / 10 \text { times feed volume }\end{array}$ \\
\hline Liquid Reflux & 30 times feed rate \\
\hline Distillation Temperature & $\begin{array}{l}60^{\circ} \mathrm{C} \text { Nominal (varies from top to bottom due to } \\
\text { pressure variation in column) }\end{array}$ \\
\hline \multicolumn{2}{|l|}{ Secondary Column Parameters } \\
\hline $\begin{array}{l}\text { Product water tritium } \\
\text { concentration }\end{array}$ & $\begin{array}{l}0.1 \text { times concentration of feed transferred from } \\
\text { primary column reboiler }\end{array}$ \\
\hline Reboiler Concenrate & $\begin{array}{l}\text { Reboiler bottoms concentrated to } 100 \text { times primary } \\
\text { column reboiler concentration or } 1000 \text { times } \\
\text { wastewater feed concentration. Net volume is } .001 \\
\text { times wastewater feed volume }\end{array}$ \\
\hline Liquid Reflux & $\begin{array}{l}30 \text { times feed transferred from primary column } \\
\text { reboiler }\end{array}$ \\
\hline Distillation Temperature & $\begin{array}{l}60{ }^{\circ} \mathrm{C} \text { Nominal (varies from top to bottom due to } \\
\text { pressure variation in column) }\end{array}$ \\
\hline
\end{tabular}


Based on the stated assumptions, it is estimated that 230 theoretical plates are required for the primary column. The height equivalent of a theoretical plate (HETP) for this application is about 4 inches (Andreev 2007 pg. 43) using bronze gauze packing. This requires packing height of 76 feet and a total column height of approximately 100 feet for the first column.

The high reflux ratio results in high liquid and vapor flows (about 30 times the feed rate) and, consequently, large column diameters. If the feed is split into 10 parallel trains each primary column is $\sim 24 \mathrm{ft}$ inside diameter. Each secondary column is estimated to require about 170 theoretical stages with dimensions of $\sim 8$ feet diameter by 80 feet tall.

\subsubsection{Vapor Recompression}

To reduce overall energy consumption and cooling water requirements, mechanical vapor recompression (MVR) is utilized to heat the reboiler. The overhead vapor stream is compressed and condenses in the reboiler. The condensing energy of the overhead steam is used for boiling the bottoms product in the reboiler. By this method, approximately $90 \%$ of the energy used for standard distillation is conserved.

Based on the assumed conditions stated above, each primary and secondary distillation column would require 4,800 and 430 horsepower respectively for vapor recompression. Total compression horsepower for the 10 distillation trains is about 52,000 horsepower or $40 \mathrm{MW}$ of power. Assuming a nominal power cost of $\$ 0.04$ per kilowatt hour and operation $70 \%$ of the time, power is estimated to cost $\$ 10$ million/year or $\sim \$ 0.27$ per gallon for recompression energy alone. While this is lower than earlier estimates, it is clear that the total costs would be more than an order of magnitude higher than costs for SALDS disposal or typical pump and treat projects (see Section 3.4 for additional information on relative costs between mitigation options).

\subsubsection{Application at the Hanford Site}

Distillation has not been used to treat large volumes of tritiated wastewater as needed for the Hanford application. As discussed in earlier evaluations, the technology is expected to work; however, the capital cost is expected to be high. The process would require a large number $(\sim 10)$ of 24' diameter primary towers each with 4,600 hp compressors plus additional smaller second stage columns and compressors. The capital and operating costs for water distillation would be more than an order of magnitude higher than costs for SALDS disposal or typical pump and treat projects (see Section 3.4 for additional information on relative costs between mitigation options). Required energy consumption would also be very high. Therefore, use of this technology can not be justified to recover of the trace amount of tritium in the Hanford ETF outfall.

\subsubsection{Combined Electrolysis Catalytic Exchange}

Combined electrolysis catalytic exchange (CECE) is one of several processes based on use of the hydrogen/water exchange equilibrium reaction (Equation 1) that favors formation of liquid HTO when liquid $\mathrm{H}_{2} \mathrm{O}$ is contacted with tritiated hydrogen (HT) gas (Sienkiewicz and Lentz 1988).

$$
\mathrm{HT}(\mathrm{g})+\mathrm{H}_{2} \mathrm{O}(\mathrm{l}) \leftrightarrow \mathrm{HTO}(\mathrm{l})+\mathrm{H}_{2}(\mathrm{~g})
$$


The CECE process has a high isotopic separation factor at near ambient temperature and pressure operating conditions. A catalyst is required for the reaction to proceed at an appreciable rate, and development of improved hydrophobic catalysts in recent years has been key to commercial success of the process.

The CECE process requires electrolysis of all feed water plus some deionized water used for stripping (approximately 1.4 times the feed flow is electrolyzed).

$$
\begin{array}{ll}
2 \mathrm{H}_{2} \mathrm{O}_{(1)} \rightarrow 2 \mathrm{H}_{2(\mathrm{~g})}+\mathrm{O}_{2(\mathrm{~g})} & \mathrm{E}_{0}=1.229 \mathrm{~V} \\
2 \mathrm{HTO}_{(1)} \rightarrow 2 \mathrm{HT}_{(\mathrm{g})}+\mathrm{O}_{2(\mathrm{~g})} & \mathrm{E}_{0}>1.229 \mathrm{~V}
\end{array}
$$

The electrolysis separates tritiated water into elemental hydrogen $\left(\mathrm{H}_{2}\right)$, tritiated hydrogen $(\mathrm{HT})$, and oxygen $\left(\mathrm{O}_{2}\right)$ gases. $\mathrm{H}_{2} \mathrm{O}$ is more easily electrolyzed than $\mathrm{HTO}$, so that $\mathrm{H}_{2} \mathrm{O}$ is depleted from the liquid causing the HTO concentration in the electrolyzer liquid to increase. The CECE process is energy intensive because of the requirement to electrolyze 1.4 times the feed water.

A variation on the CECE process uses a palladium membrane reactor (discussed in section 3.1.5) to separate elemental hydrogen from water to provide the required elemental hydrogen feed to the catalytic exchange unit. This has the advantage of eliminating the electrolysis cells and their associated power consumption. However, it has the disadvantage that a reducing agent (e. g. carbon monoxide) be must be added to drive the chemical reactions that split hydrogen from water.

\subsubsection{Process Description}

A schematic drawing of a CECE process is shown in Figure 4. The process consists of countercurrent gas/liquid exchange columns packed with catalyst beds, an electrolysis cell, and a hydrogen/oxygen recombiner (omitted if hydrogen co-production is desired). A platinum based hydrophobic solid catalyst is used. Tritiated water is added mid-column. As the water flows down the column, the tritiated hydrogen is transferred from the rising gas stream to the descending liquid stream by Equation 1.

The rising hydrogen gas stream is partially depleted in tritium in the bottom half of the upper section of the column. In the top half of the upper section, clean water further reduces the tritium content of the rising hydrogen, resulting in a hydrogen stream exiting the top that is nearly exhausted of tritium.

The combined water stream (feed plus added clean water) exits the bottom of the column to an electrolysis cell where it is electrolyzed to oxygen, hydrogen, and tritiated hydrogen gases by Equations 2 and 3. The enriched tritium stream can be taken from the bottom of the column as tritiated water or tritiated hydrogen gas depending on the desired form of the product.

\subsubsection{Process Development}

An early version of this process was used to remove tritiated water from liquid wastewaters to reach discharge-level concentrations of $20,000 \rho \mathrm{Ci} / \mathrm{L}$ in the Tritium Aqueous Waste Recovery 
System (TAWRS) at the U.S. Department of Energy (DOE) Mound Facility (Ellis 1982), (Sienkiewicz and Lentz 1988). System capacity was on the order of 2-liters per hour. 
DOE/RL-2009-18

Revision 0

Figure 4. Combined Electrolysis Catalytic Exchange Process

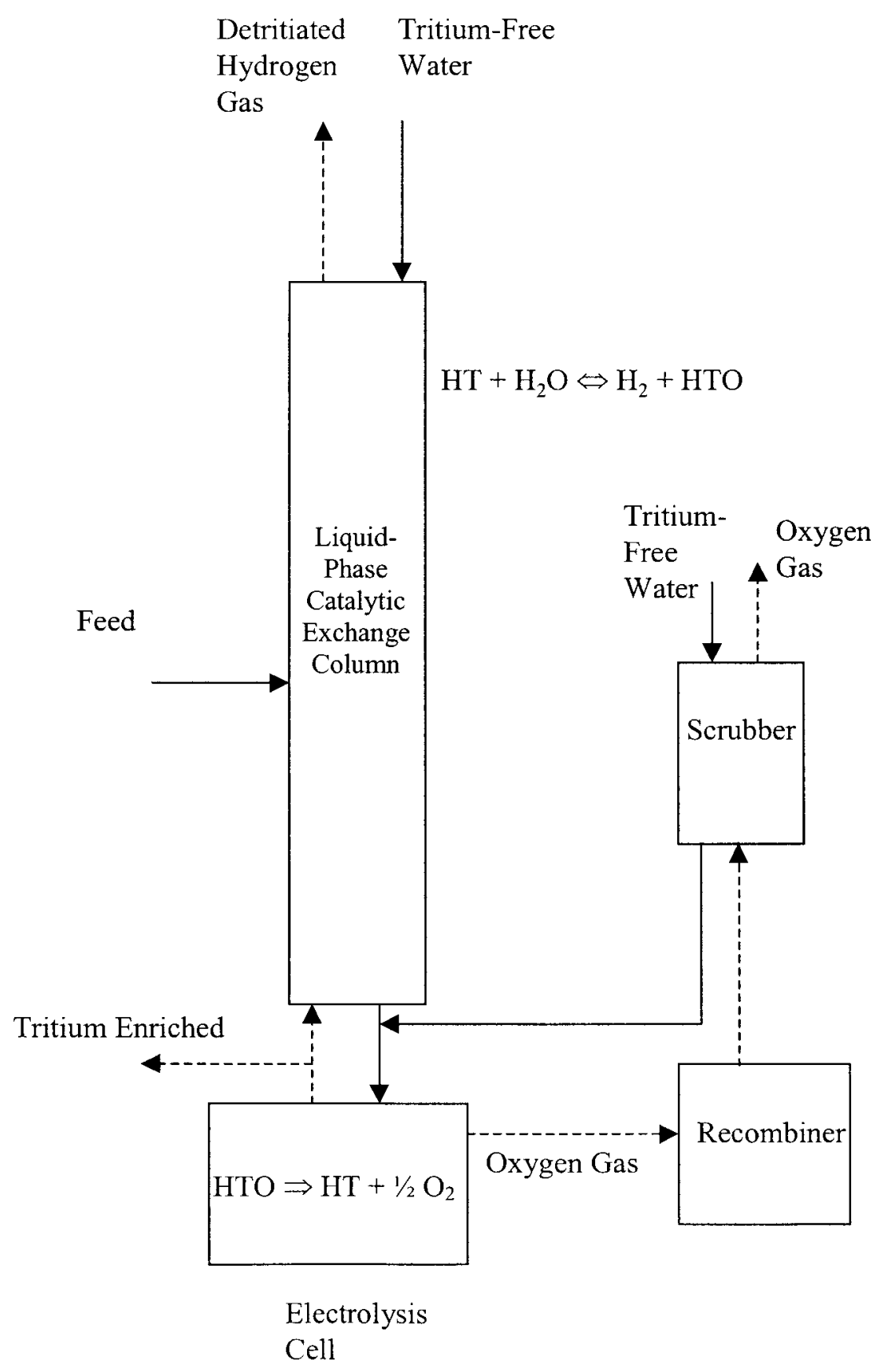


A CECE type pilot plant to recover tritium from light water was built and operated in Japan for over 14 years in connection with the Fugen reactor. The plant capacity was 3.6 liters per day of feed, and HTO was concentrated by a factor of $10^{4}$ (Isomura et al. 1988).

The CECE process has been the subject of active development work in recent years. The work includes catalyst development and testing, improvements to electrolytic cells, optimization of system and component designs, and industrial prototype construction and operation. Most of this work is aimed at tritium separation for heavy water reactors or to support the fusion reactor program.

Hydrophobic platinum based catalysts were initially developed by AECL and the Chalk River National Laboratory (Sienkiewicz and Lentz 1988). Catalysts from additional developers have recently been subjected to testing. Active work on catalyst development/testing, process optimization, demonstration testing, and new commercial production facilities have been reported at sites in Russia, Germany, the United Kingdom (UK); Korea, Romania, and China, (Perevezentsev et al. 2002), (Braet and Bruggeman 2003), (Cristescu et al. 2002), (Cristescu et al. 2003), (Cristescu et al. 2006), (Cristescu et al. 2008), (Alekseev et al. 2003), (Alekseev et al. 2002), (Fedorchenko et al. 2001), (Fedorchenko et al. 2005), (Fedorchenko et al. 2007), (Ying 2008), (Vasut 2008), (Son 2007), (Shmayda, C. R. 2007).

Electrolytic cells are an important part of the CECE process. Recent development and testing focused on use of a solid polymer electrolyte/membrane. This reduces the cell size to about $1 / 3$ that of the more conventional alkaline cells. Active development and testing of improved electrolytic cells has been reported by several sites (Ogata 2003), (Ogata 2005), (Cristescu et al. 2006), (Michling 2008). Work on the palladium membrane reactor has also progressed, potentially allowing the electrolytic cells to be eliminated by using a reducing agent (e. g. CO, coke, or charcoal) to split the hydrogen from water (see section 3.1.5).

A larger version of the process used at the Japanese Fugen reactor has been designed for use with the proposed International Thermonuclear Experimental Reactor (ITER), a fusion reactor (Iwai et al. 2002). A significant amount of development work on CECE has been performed to support the ITER, which is being constructed at Cadarache, France with multinational technical participation and funding (Cristescu et al. 2007), (Cristescu et al. 2008), (Michling 2008), (Yamanishi 2008). The ITER project recently issued a request for tenders for design of CECE based water detritiation systems to be installed at Cadarache (ITER 2008). The technical specification calls for use of solid polymer electrolyte cells and gas/liquid phase catalytic exchange columns. Overall system capacity is $60 \mathrm{~kg} / \mathrm{hr}$ of wastewater (about $1 \mathrm{liter} / \mathrm{min}$ ) and includes three identical process trains, each sized to process $20 \mathrm{~kg} / \mathrm{hr}$ of tritiated water. A cryogenic isotope separation system will be used for recovery of concentrated tritium from the partially concentrated product of the CECE system.

AECL constructed and completed a successful demonstration of the CECE process as part of its Prototype CIRCE Plant demonstration project at Hamilton, Ontario Canada (Klem 2004). The pilot plant uses a $7.5 \mathrm{kA}$ electrolysis cell and a 2-inch diameter column with a total water flow of approximately $1.5 \mathrm{~L}$ per hour. During testing, a detritiation factor exceeding 30,000 was achieved (Miller 2001). A two part demonstration of the CECE process was also successfully 
completed at Chalk River (Miller et al. 2002), (Graham et al. 2002). The first part was to demonstrate upgrading of heavy water and the second part demonstrated a detritiation decontamination factor of over 1,000 and as high as 50,000 treating tritium contaminated heavy water.

Recent papers (Aleskeev et al. 2003), (Aleskeev et al. 2007), (Federchenko 2005) provide information on a CECE pilot plant at the Petersburg Nuclear Physics Institute that has been operated since 1995 . The plant has processing capacity of about $4.5 \mathrm{~kg}$ per day (about $4.5 \mathrm{~L}$ per day) and has demonstrated tritium decontamination factors of 1,000 when operated with heavy water (a more difficult separation than with light water). Multiple operating modes and conditions have been tested.

A CECE treatment system is planned for the Joint European Torus (JET) facility operated by the UK Atomic Energy Authority at Culham Oxfordshire (Perevezentsev et al. 2002), (Lasser et al. 2003), (Perevezentsev 2008). In support of the JET program, CECE process development work has been underway for a number of years at Tritium Laboratory Karlsruhe in Germany (Lasser et al. 2003), (Cristescu et al. 2003), (Cristescu et al. 2006), (Cristescu et al. 2008).

The active development and implementation work at multiple sites indicates CECE is a viable process and should continue to improve over time.

\subsubsection{Application at the Hanford Site}

An evaluation conducted by the AECL for the Savannah River Site concluded the CECE process should be considered as a viable process for detritiating water (Miller 1999). Since that time there has been considerable development and demonstration of the process for different applications and the process appears technically feasible.

A major operating cost is electrical power. The CECE process requires electrolysis of all feed water plus some deionized water used for stripping (approximately 1.4 times the feed flow is electrolyzed). About $164 \mathrm{MW}$ of power to the electrolyzers is required to support a nominal $100 \mathrm{gpm}$ wastewater feed rate. Power losses for conversion of incoming power to the low voltage direct current required for electrolysis and other power uses increase required power further above this value. This process requires costly hydrophobic catalyst, considerable cost for electrolytic cells, and handling of hydrogen gas at near-atmospheric pressures for the separation. Confinement systems are required for the concentrated tritium product for protection of workers, the environment and public. Detailed site specific cost estimates are not available and testing has not been performed with Hanford specific waste compositions.

Feed for this process needs to be water with low levels of organic and inorganic contaminants. Water that has been processed at ETF is likely to work well as a feed because this wastewater is essentially free of contaminants other than tritium. Full characterization and possibly testing work would be needed to determine if additional pretreatment is needed for specific candidate waste streams. 
A tritium enriched waste stream will be produced in addition to tritium depleted water or hydrogen. This can be in the form of HT in hydrogen gas from the electrolytic cell or water with elevated tritium compared to the feed water. The HT could be loaded on a metal as a hydride or tritiated water could be dispositioned as a grouted waste form. This stream is small compared to the wastewater feed. Cost of dispositioning the waste will depend upon the method, and could be significant.

Detailed site specific cost estimates are not available for treating Hanford tritiated water. However, a recent cost estimate by AECL (Miller 1999) prepared for the SRS provides a rough idea of costs that may be expected. The estimate indicated a treatment cost of $\sim \$ 0.32$ per $\mathrm{L}$ $(\$ 1.2$ per gal) for treating $1.3 \mathrm{~L} / \mathrm{s}(20 \mathrm{gpm})$ of water with a tritium concentration of $200 \mu \mathrm{Ci} / \mathrm{L}$ based on 1999 costs and an electric power cost of $\$ 0.02$ per kWh. With escalation for today's capital, operating and power costs this estimate would approach $\$ 2$ per gallon. Since the energy cost for CECE tritium separation is approximately four times the cost for conventional water distillation using mechanical vapor recompression, the CECE process is not expected to be competitive for treating Hanford tritiated water.

\subsubsection{Bithermal Hydrogen-Water Process}

The bithermal hydrogen-water process is based on the same hydrogen/water exchange reaction as the CECE process (see Section 3.1.2), and may be able to use similar catalysts. However it does not require electrolysis of the feed water, but instead relies on a recycled stream of hydrogen coupled with dual temperature separations columns. The bithermal hydrogen-water process was discussed in the 1999 evaluation report (Jeppson 1999).

\subsubsection{Process Description}

This process consists of cold-stripping and cold-enriching columns and hot-enriching and hotstripping columns stacked in a vertical orientation with hydrogen gas flowing upward countercurrent to the aqueous streams, as shown in Figure 5. Tritiated water to be treated is introduced between the cold-stripping and cold-enriching columns. Three conditions are important to maximizing separation factors: 1) use of an active hydrophobic catalyst, 2) temperature control to enhance the stripping and enriching conditions, and 3) high pressure. Hydrophobic catalysts are used, similar to the CECE process. However, some catalysts developed for CECE are not suitable because their upper temperature limit is about $100^{\circ} \mathrm{C}$, which is lower than the optimum temperature for the Bithermal process (Andreev 2007).

In the upper "cold stripper" section, non-tritiated water is used to absorb tritium from the circulating hydrogen. The resulting hydrogen gas, essentially free of tritium is recirculated to the hot-stripping column to remove tritium from the wastewater to be discharged. The tritium-rich product stream is withdrawn from between the cold and hot enrichment columns. The columns are operated at near 49 atmospheres pressure to achieve maximum separation factors. The hot enrichment and stripping column sections are operated at about $443^{\circ} \mathrm{K}\left(170^{\circ} \mathrm{C}\right)$, and the coldstripping and cold-enrichment column sections are operated at about $323^{\circ} \mathrm{K}\left(50^{\circ} \mathrm{C}\right)$. 
Figure 5. Bithermal Hydrogen-Water Process

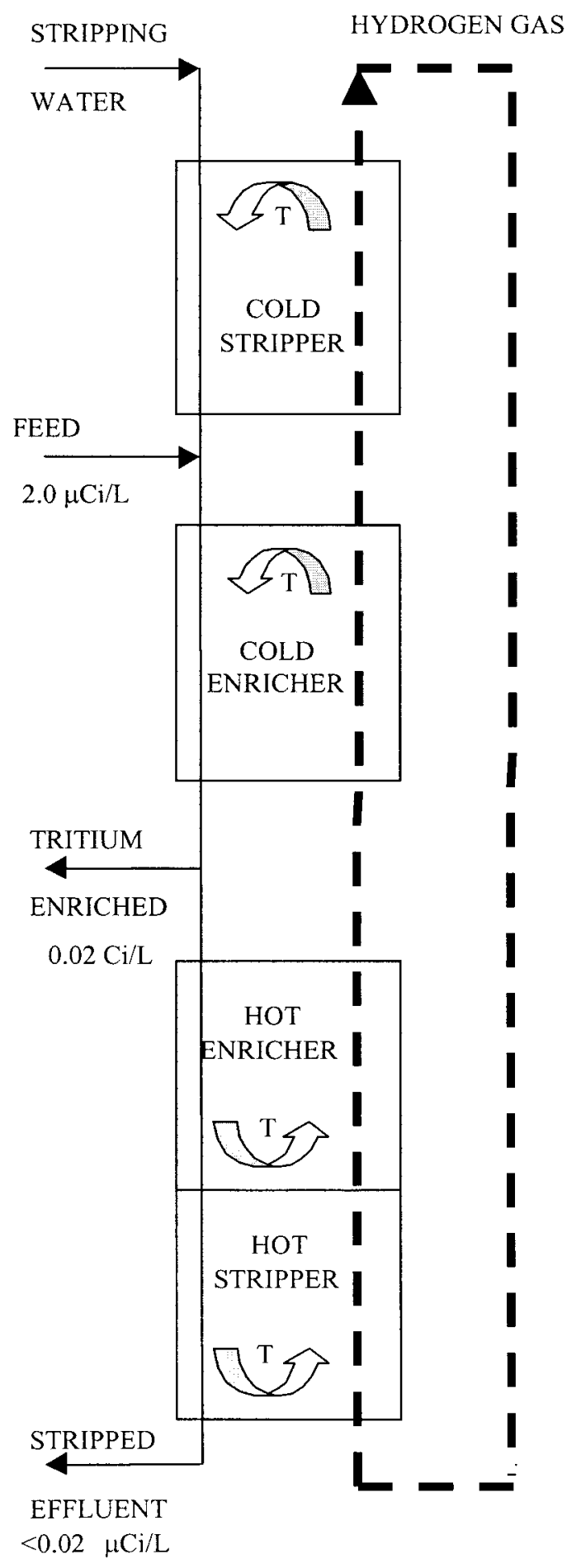




\subsubsection{Recent Developments}

The bithermal hydrogen-water process uses the same chemistry and similar catalysts to those used for the CECE process. Therefore much of the development work on the CECE process is directly or indirectly applicable to bithermal hydrogen-water. A prototype unit was installed and operated successfully at the Prototype Combined Industrial Reforming and Catalytic Exchange (CIRCE) demonstration project at Hamilton, Ontario Canada (Klem 2004).

\subsubsection{Application at the Hanford Site}

Existing applications for the bithermal hydrogen-water process are for treating heavy water; however, it appears feasible to adapt the technology for treatment of Hanford Site wastewater. This process does not require electrolysis of the feed water to change phases of the feed stream, but operation with large volumes of hydrogen gas at high pressure, heating to moderately high temperatures and significantly higher recirculation flows compared to the CECE process. The process is expected to be capable of reducing tritium concentrations from levels typical of Hanford wastewaters to less than the MCL of $20,000 \rho \mathrm{Ci} / \mathrm{L}$ for the depleted discharge stream while producing a small volume tritium-rich stream of $>0.02 \mathrm{Ci} / \mathrm{L}$. The AECL has stated that this process can be designed to process 300 to 500 liters per minute with no obvious difficulty.

Feed water for this process needs to contain low levels of organic and inorganic contaminants. Water that has been processed at ETF is likely to work well as a feed because this wastewater is essentially free of contaminants other than tritium. Full characterization and possibly testing work would be needed to determine if additional pretreatment is needed for specific candidate waste streams.

Concerns with this process include: 1) the containment of tritiated water and tritiated hydrogen gas under high pressure, 2) safety with the use of high-pressure hydrogen gas in the process, and 3 ) the fact that the process has not been used on a large industrial scale. In addition, the process is much more sensitive to control of the process flows than is the CECE process. Because electrolysis of all the feed is not required, power costs are expected to be lower than for the CECE process. However the separations columns, catalyst beds, and the internal stream flows are much larger. As in the case of the CECE process, a method must be provided to disposition the concentrated tritiated water stream. As stated in the 1999 evaluation report, the process (Miller 1999) was evaluated to be only slightly more costly than the CECE process for the $20 \mathrm{gpm}$ scenario they evaluated. Lower decontamination factors required at Hanford compared to SRS could tend to favor the bithermal hydrogen-water process because its costs are more sensitive to required separation efficiency. Total treatment costs (capital, utilities, labor, etc.) for this process are expected to be similar to the costs for the CECE process with the lowest cost option depending on capacity, operating duration, power cost, and other site specific factors.

\subsubsection{Girdler Sulfide Process}

Like the bithermal hydrogen water process, the Girdler Sulfide (GS) process uses cold and hot columns and a recirculating gas to drive the separation process. However, in the GS process hydrogen sulfide is the recirculating gas and no catalyst is required. The GS process is described 
in more detail in Jeppson et al. (1997). This mature process has been long used for heavy water production and is expected to be adaptable to Hanford Site wastewater treatment requirements. No significant recent developments were identified for this process and although it is expected to be feasible, the process has major safety concerns. The safety concerns are focused around the high-pressure (20 atm) and the highly toxic and corrosive hydrogen sulfide gas used in the process.

In the Miller (1999) evaluation, the GS process was judged to cost somewhat more than the CECE process or a bithermal hydrogen-water process for the specific scenarios evaluated. Costs of about $\$ 0.5$ per L ( $\$ 2$ per gal) (Miller 1999) were estimated to reduce tritium concentrations from $200,000,000 \rho \mathrm{Ci} / \mathrm{L}$ to $<20,000 \rho \mathrm{Ci} / \mathrm{L}$ at a flow rate of $1.3 \mathrm{~L} / \mathrm{s}(20 \mathrm{gpm})$. The lower tritium concentrations typical at Hanford are expected to reduce the cost only slightly.

\subsubsection{Palladium Membrane Reactor}

The palladium membrane reactor (PMR) has been developed for separation of hydrogen gas from other molecules (i.e. oxygen, carbon monoxide, and carbon dioxide). It is not a direct method for production of hydrogen isotopes, but the PMR generates a crude product for further purification by hydrogen isotope separation processes (e.g. $\mathrm{H}_{2} / \mathrm{H}_{2} \mathrm{O}$ catalytic exchange, cryogenic distillation, gas diffusion, thermal diffusion, or gas adsorption).

\subsubsection{Process Description}

The PMR directly combines two techniques which have been long utilized for hydrogen processing (Willms 1995):

- The water gas shift reaction:

$$
\mathrm{CO}+\mathrm{H}_{2} \mathrm{O} \leftrightarrow \mathrm{H}_{2}+\mathrm{CO}_{2}
$$

A platinum or nickel catalyst is typically used to increase the rate of the water gas shift reaction at practical operating temperature.

- Palladium/silver membrane separator

Palladium silver membranes selectively allow diffusion of hydrogen isotopes with essentially zero diffusion of the other gaseous species $\left(\mathrm{CO}, \mathrm{H}_{2} \mathrm{O}\right.$, and $\left.\mathrm{CO}_{2}\right)$. These membranes have long been used for production of ultra pure hydrogen.

A gaseous mixture containing carbon monoxide $(\mathrm{CO})$ and water vapor is fed to the palladium metal reactor. The feed mixture can be produced by boiling the feed water and blending it with $\mathrm{CO}$, or by reacting the feed water at high temperature with a reducing agent such as coke, charcoal, or hydrocarbons.

The PMR contains a bed of catalyst (typically nickel or platinum) where hydrogen is split from the water and $\mathrm{CO}_{2}$ is produced. Hydrogen is removed by diffusion through palladium tubes located inside the catalyst bed. Removal of hydrogen allows the shift reaction to proceed further 
to the right increasing conversion of water to hydrogen. The high purity hydrogen stream is transferred to a second process for separation of tritium from the other hydrogen isotopes.

To provide a high extent of conversion of water to hydrogen, a substantial pressure differential is required between the catalytic reaction side of the palladium silver membrane and the high purity hydrogen permeate side of the membrane. For tritium separation, use of a vacuum on the permeate side has typically been used to provide the pressure differential. Multi-stage vacuum units may be considered to reduce energy consumption by removing most of the hydrogen at moderate vacuum followed by succeeding steps with higher permeate vacuum.

\subsubsection{Process Development}

The palladium metal reactor has been developed for tritium processing by Los Alamos National Laboratory. The technology was proposed and tested for tritium removal and recovery from tritiated water, tritiated hydrocarbons, and other organics (Willms 1995), (Birdsell 1999), (Drake 1996). A production scale demonstration system was built and operated at the Savannah River Site (SRS) between April 2001 and May 2003. The SRS system was successfully used to recover tritium from tritiated water that had been adsorbed on molecular sieve sorbents (Sessions 2005). More recently a palladium membrane reactor has been incorporated as part of a commercial tritium recovery system at a commercial radiochemical processing facility (Bonnet $2008 \mathrm{~A}$ ).

The process combines palladium membrane technology for hydrogen separation and water gas shift reaction catalysts that are considered to be established proven technology. Primary technical challenges are related to optimization of equipment and process design and integration into an overall system for tritium processing.

\subsubsection{Application at the Hanford Site}

The PMR is expected to provide some incremental cost savings for selected tritium separation processes depending on site specific factors. The isotope separation processes that would be supported by the palladium membrane reactor have not been used at near the scale required for Hanford wastewater treatment. These processes are considered to be excessively costly and impractical for the Hanford Site application. The process also requires handling of large volumes of toxic and/or potentially explosive gas mixture $\left(\mathrm{CO}\right.$ and $\left.\mathrm{H}_{2}\right)$ resulting in additional safety hazards.

\subsubsection{GE Integrated Systems}

GE-Hitachi Nuclear Energy (GE) has developed several integrated system concepts for processing tritium contaminated wastes. These systems are designed to reduce environmental emissions and in some cases to recover tritium for beneficial use.

The initial integrated process was installed at the GE manufacturing site located near Cardiff, UK, and resulted in a large reduction in tritium discharges to the environment (Bonnett 2008A). Building on this experience, GE has developed additional separations technology and integrated 
system concepts, and is marketing these commercially. Key features for three applications are outlined in (Bonnett 2008A).

- Cardiff UK Process. This process supports a facility that has been producing tritiumlabeled chemicals since the 1940s. Thermal oxidation is performed first to convert the tritium component of organic material to tritiated water. The tritiated water is then processed through a water distillation system that concentrates the tritium in the bottoms. The concentrated tritiated water is mixed with carbon monoxide gas and fed to a PMR (Section 3.1.5) where the hydrogen isotopes are split from the water and separated from reaction products. The mixed hydrogen isotopes containing about 2000 PPM tritium are fed to a thermal diffusion system where tritium is separated from the other hydrogen isotopes, producing a concentrated product that is $>99 \%$ tritium. Product tritium is recycled for beneficial use within the facility.

- Heavy Water. For heavy water decontamination, the proposed GE system uses liquid phase catalytic exchange (hydrogen/water) as the initial process step. The method for splitting elemental hydrogen isotopes from the feed water is not specified in the reference, but would presumably be either electrolysis or the palladium membrane reactor depending on site specific conditions. The tritium rich stream from the catalytic exchange reactor is fed to gaseous diffusion and then thermal diffusion steps to produce a high purity tritium product.

- ITER Fusion Reactor. To support tritiated water cleanup and tritium recycling for the ITER, the GE process uses water distillation as the initial step for processing. Bottoms from the water distillation system are transferred to liquid phase catalytic exchange. The tritium enriched stream from liquid phase catalytic exchange is processed by a gaseous diffusion cascade to produce a high concentration tritium product and a deuterium product.

In addition to the above, GE has evaluated systems for light water reactors. A recently completed study recommended a water distillation system for cleanup of tritiated wastewater at a commercial light water reactor (Bonnett 2008B). Mechanical vapor recompression technology may be beneficially used to reduce energy and cooling water consumption for this application (See Section 3.1.1 for additional discussion of distillation and mechanical vapor recompression).

\subsubsection{Application at the Hanford Site}

The entry of GE into the tritium waste processing market is of interest because they bring an array of technology and expertise that can be brought to bear on tritium abatement issues. However, the specific tritium processes and systems they are involved with are at a very small scale compared to the Hanford Wastewater volumes. While the proposed process concepts may provide some incremental improvement in performance and cost, they do not represent a major breakthrough that would substantially reduce cost for the Hanford application. 


\subsubsection{Other Industrial Hydrogen Isotope Separation Processes}

Recent work was identified on industrial or semi-industrial adsorption based separation processes (e.g. Antoniazzi 2006, Sun 2008 and Staack 2008) and diffusion-based processes (Bonnett 2008). These processes have relatively low capacity and are reasonably applicable at much smaller scale than the required capacity for processing Hanford wastewater. In addition, the hydrogen isotopes must be split from the water molecules prior to transfer to the isotope separation process. (e. g. using electrolysis or the palladium membrane reactor). It is therefore concluded that these processes are not reasonably applicable for Hanford Wastewater treatment. Other than these processes, no new development work, evaluations, or implementation projects for other industrial hydrogen isotope separation processes were identified. The earlier evaluation reports (Jeppson et al. 1997) (Jeppson 1999), and (Penwell 2001) should be consulted for information on other processes that were previously evaluated.

\subsection{DEVELOPMENTAL HYDROGEN-ISOTOPE SEPARATION TECHNOLOGIES}

This section summarizes new information identified on developmental hydrogen isotope separation technologies that have not been demonstrated on an industrial scale.

\subsubsection{Tritium Sorbent Process}

The sorbent based Tritium Resin Separation Process developed by Molecular Separations Incorporated was discussed in the 1999, 2001, and 2004 evaluation reports (Jeppson 1999), (Penwell 2001), (Klem 2004). In this process, a proprietary solid sorbent material is used. The sorbent has water of hydration sites that are selective for tritiated water $\left(\mathrm{T}_{2} \mathrm{O}, \mathrm{HTO}\right)$ over protinated $\left(\mathrm{H}_{2} \mathrm{O}\right)$ water. Tritiated water is selectively adsorbed onto the sorbent as it contacts the contaminated water, and the sorbent is periodically regenerated by heating. Refer to evaluations in prior reports for a more detailed process description.

The sorbent based process was evaluated by the Electrical Power Research Institute (EPRI), including bench scale process testing. Major findings of the EPRI Assessment Test Program (EPRI 2002) are summarized below:

1. The Tritium Resin Separation Process does selectively remove tritiated water from solution by a hydration mechanism. Removal efficiency rates ranges from 0 to $39 \%$ in beaker and column tests. The highest removal rates were seen in using an inorganic exchange resin.

2. At this point the TRS Process has not been shown to be an economically viable process technology. The technology can be characterized as having extremely short runs, long drying cycles and relatively low tritium removal efficiency per cycle.

3. Test requirements confirmed the requirement of complete removal of ionic and organic contaminants prior to the process. 
4. The proposed use of organic exchange resin resulted in a major failure due to rapid degradation of the media due to drying temperature.

5. Operation of the test columns as a "fluidized bed" resulted in a major loss in the tritium decontamination factor and did not allow for the determination of the final tritium removal capacity for the media.

Based upon theses finding, the MSI TRS process has not been demonstrated to be suitable for removing tritium from Hanford wastewaters where tritium removal efficiency of $99 \%$ is needed, and the sorbent bed must be regenerable. A previous evaluation (Klem 2004) also concluded that the treatment cost would be excessive even if the process was made to work. As a result of these findings, the TRS process is not viable for Hanford tritiated water treatment at this time.

\subsubsection{Other Developmental Processes}

Earlier evaluations included additional developmental technologies for separation of hydrogen isotopes, including: Membrane mediated separation, laser induced tritium separation, kinetic isotope effects, and variations of the dual temperature liquid phase catalytic exchange processes. No significant developments were identified for these processes, and no new processes that are potentially applicable to Hanford wastewater were identified in the current review. See earlier evaluation reports for information on these processes.

\subsection{OTHER TRITIUM MITIGATION TECHNOLOGIES FOR WASTEWATERS}

There are several concepts for delaying movement of tritium contaminated groundwater plumes thereby maximizing the time before contaminated groundwater reaches site boundaries. These concepts are based upon the fact that tritium decays with a half-life of 12.3 years. Other mitigation methods involve evaporation or incineration of the tritiated water with releases directly to the atmosphere.

\subsubsection{Pump and Recharge}

The pump and recharge concept extracts tritium contaminated water from the ground and recharges it at a location where the movement of groundwater will take longer for the contaminated groundwater to reach site boundaries. Treatment to remove contaminants other than tritium may be performed prior to recharge. In some cases this treatment approach is combined with methods to minimize the natural recharge to the aquifer in order to minimize the total volume of water requiring treatment. 
The pump and recharge concept was used at the Savannah River Site between 1998 and 2003 and at Brookhaven National Laboratory between 1997 and 2000 and again in 2007. The 1999 evaluation report (Jeppson 1999) discussed in detail the methods used at Savannah River and at Brookhaven.

Pump and recharge at the Savannah River Site was stopped in mid-2003 because of the high cost of groundwater treatment ( $\$ 0.012$ per $\mathrm{L}$ or $\$ 0.047$ per gallon) and about a 50 to $70 \%$ reduction of the tritium concentration (up to $50,000,000 \rho \mathrm{Ci} / \mathrm{L}$ or 10 times the maximum tritium concentration in groundwater at Hanford) in the plume after five years of pumping and upgradient recharging (Flach 2002, Blount et al. 2003, Blount 2003). Operating cost for the pumptreat-recharge was about $\$ 50,000$ per day. Pump and recharge at Brookhaven was stopped in 2000 because tritium levels in the vicinity of the extraction wells decreased to below the average minimum detection limit of the BNL Analytical Services Laboratory (343 $\rho \mathrm{Ci} / \mathrm{L}$ ) (BNL 2002a, BNL 2002b). The decrease is a result of the combined effects of radioactive decay, dilution and dispersion. The Brookhaven pump and recharge system was placed in standby in 2000 and was reactivated in 2007 (BNL 2008). In addition to the pump and recharge scheme, low flow extraction of highly contaminated groundwater was undertaken at Brookhaven during 2000 and 2001 to accelerate cleanup of the plume. A total of 95,000 gallons of groundwater were pumped from ten temporary wells. The water was transported off-site for disposal (Dorsch 2007).

\subsubsection{Application at the Hanford Site}

As stated in the 1999 report, groundwater pumping at the $20,000 \rho \mathrm{Ci} / \mathrm{L}$ concentration front would cover a distance of over $40 \mathrm{~km}$ (Jeppson 1999, Hartman 2003). The large distance of the front, the number of wells which would be required, and the large volume of water which would have to be pumped and potentially treated to meet applicable state and federal limits except for tritium preclude this concept from being economically feasible.

An additional factor that makes the concept not feasible at the Hanford site is the increase in volume that would need to be pumped and potentially treated each year. Although the recharge rate is low, the additional amount of water to pump and potentially treat each year would increase significantly because of the large volume of the contaminated plume.

\subsubsection{Barrier Formation}

Two types of subsurface barriers have been demonstrated at the DOE Sites. The frozen soil barrier concept was discussed in detail in the 1999 evaluation report (Jeppson 1999). The information will not be repeated. 
Another barrier technology termed Viscous Liquid Barrier (VLB) was selected by the Brookhaven National Laboratory for groundwater remediation. Groundwater monitoring near the Brookhaven Linear Accelerator Isotope Producer (BLIP) showed tritium and other radionuclide contamination had occurred before 1998. The VLB technology was developed at Lawrence Berkley National Laboratory with funding from DOE (EM-50). It used low-pressure permeation grouting to deliver a colloidal-silica grout to the subsurface. The grout gels in place and forms a barrier to liquid movement. The VLB in conjunction with a gunite cap around the surface soil of BLIP and storm water controls would minimize the volume of surface water percolating through the contaminated soils to the groundwater. The estimated volume of soil to be treated is approximately $85 \mathrm{~m} 3$. Modeling results showed that if the flow velocity though the activated soil is reduced to less than $1 \mathrm{~cm} / \mathrm{yr}$, short-lived isotopes including tritium will not reach the aquifer at levels exceeding the drinking water standard (Heiser et al. 2000).

The VLB installation was completed in 2000 at a cost of about $\$ 436,000$ (North-Abbot 2004, Heiser et al. 2000). The cost includes site characterization, grout compatibility and optimization testing, modeling, and barrier integrity verification and planning documents. According to groundwater monitoring data, the actions taken to date have been highly effective in eliminating the BLIP source of groundwater contamination. Evaluation of barrier performance is continuing (Sullivan 2003). The Department of Energy, EPA, and New York State have recently agreed that "continued inspections, and maintenance of the cap, groundwater monitoring, and institutional controls in addition to the previously completed work (summarized above) are sufficient to support the selection of no further action," (BNL 2007).

At SRS a sheet pile dam has been used as a barrier since 2000. This barrier was designed to reduce tritiated water discharges to Fourmile Branch and has successfully reduced tritium concentrations in water discharged to Fourmile Branch by $65 \%$ (SRS 2008). This dam resulted in tritiated water accumulation by a retention pond. This water is treated by Phytoremediation (Section 3.3.4).

\subsubsection{Application at the Hanford Site}

Application of soil barrier technology is not economically feasible for tritium remediation in bulk groundwater because of the large volume of subsoil that would have to be frozen or injected with grout. Use of sheet pile barriers is also not applicable to the Hanford situation. 


\subsubsection{Decay in Slow Moving Groundwater}

The 12.3 year half life of tritium allows storage to be considered as a mitigation method. Reduction of tritium content versus storage time is illustrated by Table 2.

Table 2. Tritium Decay Versus Storage Time

\begin{tabular}{|l|l|l|}
\hline Storage Time & Tritium Reduction & Decontamination Factor (DF) \\
\hline 41 years & $90 \%$ & 10 \\
\hline 81 years & $99 \%$ & 100 \\
\hline 122 years & $99.9 \%$ & 1000 \\
\hline
\end{tabular}

One approach for mitigation of tritium in wastewater is to store it underground in a stagnant or slow moving aquifer where it will be isolated from the general environment and human consumption for an extended period of time. This approach has the advantages of low cost and low energy consumption provided a suitable storage location is available.

\subsubsection{Application to the Hanford Site}

Since 1995, a state-approved land disposal site (SALDS) has received tritium contaminated effluents from the ETF. Tritium in this effluent is mitigated by storage in slow moving groundwater to allow extended time for decay before the water reaches the site boundary. This method isolates the tritium from the general environment and human contact until it has decayed to acceptable levels.

The SALDS is located just north of the 200 West Area on the Hanford site and began receiving tritiated wastewater from the ETF in December 1995. Treated wastewater from the ETF meets all applicable state and federal limits except for tritium (Ecology 2000). The majority of the tritium comes from processing liquid mixed wastes from single-shell and double-shell underground storage tanks and other radioactive miscellaneous wastes from the Hanford site. The waste discharge to SALDS is based on the average monthly flow and past performance allowed by State Waste Discharge Permit ST -4500 . The permitted average monthly flow rate is 0.25 million gallons per day or up to 90 million gallons per year.

The ST-4500 permit condition S.10 requires a tritium tracking and groundwater monitoring plan. The DOE has agreed to monitor the tritium plume created by ETF discharge and update models used to predict travel time to the Columbia River. See Barnett et al. (1997) and Barnett et al. (2003) for discussions of modeling and monitoring results. 
The ST-4500 permit indicates that computer model results predict tritium bearing effluents discharged to the ground at SALDS will take an extended period of time to travel with groundwater beneath the Hanford site before ultimate discharge to the Columbia River. Models and discharge scenarios indicate that tritium above the drinking water standard will not reach the Columbia River in detectable quantities (Ecology 2000). During the long residence time in the aquifer, most of the tritium will decay to non-radioactive helium.

Discharges from ETF to the SALDS are listed in Table 3 by date, volume, and concentration of tritium.

Table 3. Tritiated Water Discharges to the State-Approved Land Disposal Site.

\begin{tabular}{|c|c|c|c|c|}
\hline \multirow[t]{2}{*}{$\begin{array}{c}\text { Calendar } \\
\text { Year }\end{array}$} & \multicolumn{2}{|c|}{ Volume } & $\begin{array}{c}\text { Average } \\
\text { Tritium } \\
\text { Concentration }\end{array}$ & Tritium \\
\hline & (L) & (gal) & $(\rho \mathbf{C i} / \mathbf{L})$ & (Ci) \\
\hline 1995 & $2,237,000$ & 591,000 & $6,200,000$ & 13.8 \\
\hline 1996 & $28,630,000$ & $7,564,000$ & $7,500,000$ & 214.5 \\
\hline 1997 & $57,445,000$ & $15,177,000$ & 610,000 & 35.1 \\
\hline 1998 & $107,195,000$ & $28,321,000$ & 290,000 & 31.5 \\
\hline 1999 & $88,266,000$ & $23,320,000$ & 100,000 & 9.0 \\
\hline 2000 & $91,306,000$ & $24,123,000$ & 230,000 & 21.1 \\
\hline 2001 & $98,353,000$ & $25,985,000$ & 6,000 & 0.1 \\
\hline 2002 & $23,367,000$ & $22,071,000$ & 105,000 & 8.8 \\
\hline 2003 & $95,655,000$ & $25,880,000$ & 43,000 & 4.3 \\
\hline 2004 & $106,976,000$ & $28,254,000$ & $134,000^{1}$ & 14.3 \\
\hline 2005 & $22,986,000$ & $6,071,000$ & $102,000^{1}$ & 2.3 \\
\hline 2006 & $18,144,000$ & $4,792,000$ & $1,370,000^{1}$ & 24.8 \\
\hline 2007 & $32,887,000$ & $8,686,000$ & $6,520,000^{1}$ & 21.5 \\
\hline 2008 & $63,692,000$ & $16,822,000$ & 6,570 & 0.4 \\
\hline
\end{tabular}

The annual average tritium concentration may be misleading because tritiated water comes from sources with widely different concentrations and volumes. Typically, groundwater contains $<50,000 \rho \mathrm{Ci} / \mathrm{L}$ while $\mathrm{K}-\mathrm{Basin}$ and 242-A Evaporator wastewater has much higher tritium contamination, $\sim 2,000,000 \rho \mathrm{Ci} / \mathrm{L}$. Table 4 lists tritiated water discharged to SALDS by source for the past 4 years. 
Table 4. Sources of Tritiated Water to SALDS

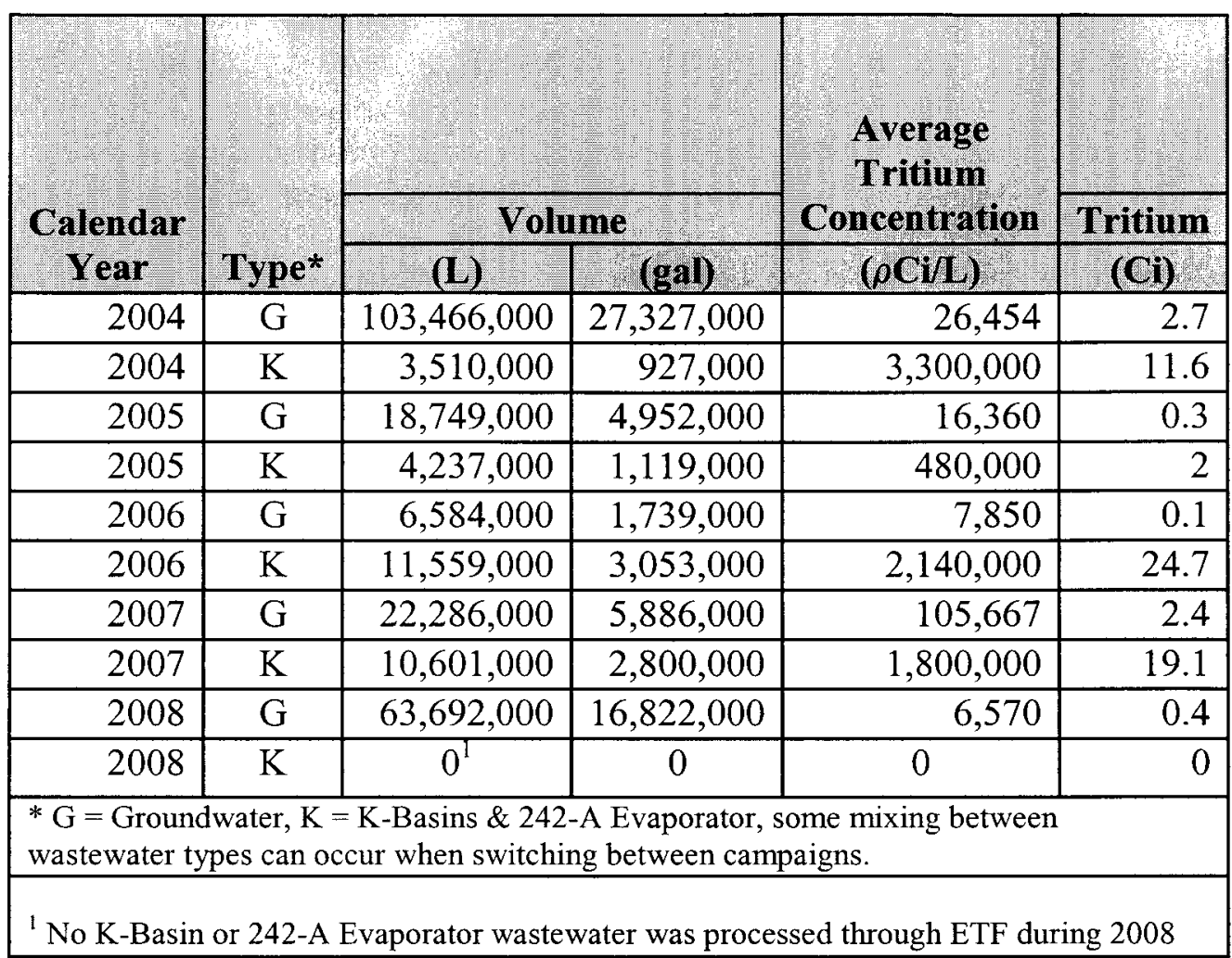

\subsubsection{Evaporation}

One approach for disposing of wastewater and ground water is evaporation with dispersion into the atmosphere. Potential evaporation methods include:

- Boiling or Mechanical Evaporation. A variety of industrial equipment is available for evaporation by boiling, including conventional indirect contact types (boilers, evaporators) and direct contact types (for example incinerators).

- Injection into an incinerator results in vaporization of the water which is discharged with the stack gas.

- Solar evaporation. Use of solar heat and movement of air to evaporate water.

- Contact with an air stream. For example air can be bubbled through the water or water can be sprayed into the air.

- Phytoremediation. Plants take in the contaminated water through their roots and the majority of the water (including tritium) is evaporated. A fraction of the tritium is also retained in the plant matter until it decays. If the water source is at or near the surface, the plant may remove water directly from the source. Alternatively the water may be pumped to the plants (i.e. use of contaminated water for irrigation). 
Three evaporation methods (Solar Evaporation, Irrigation, and Mechanical Evaporation) were considered in the 1994 Hanford Site evaluation (Allen 1994). Of 11 tritium mitigation methods evaluated, the above three received the lowest rankings (Table 7-1 of (Allen 1994)). As discussed in the following, incineration and phytoremediation have recently been selected at other DOE sites for disposal or mitigation of wastewater with trace tritium contamination.

\subsubsection{Phytoremediation}

Phytoremediation is the process of using plants to remediate contaminated areas, including soil, groundwater, and surface water. The process is being used at the Argonne National Laboratory and the Savannah River Site for tritiated water.

In phytoremediation the plants take up nutrients from the contaminated soil and use the contaminated water to grow. The plants can breakdown, trap and hold contaminants in the leaves and/or stems, and transpire the water into the atmosphere as part of natural plant growth. The transport of water in soil and vegetation and accumulation of biomass in forest trees are considered the most important physical, chemical and biological transport processes for estimating partitioning of isotopes to vegetation and the amount of fixed tritium in a forest that has been exposed to tritiated irrigation water (Diabate and Strack 1993, Murphy 1993).

The turnover time of tritiated water in the conducting outer rings of the roots and stem and in the leaves is on the order of hours to several days. The turnover time of tritiated water in the inner, older rings of the roots and stem is on the order of days to years depending on the size of the tree. Approximately 60 percent of the tritium fixed during synthesis remains in the biomass until released by decay or combustion after death of the tree. The remaining 40 percent will be exchanged with hydrogen in water (Blount et al. 2003).

Phytoremediation at Argonne National Laboratory is being performed on a site that is contaminated with tritium. The primary reasons for performing the remediation are to stop growth of the groundwater plume and to remove other contaminants in the soil and groundwater. The tritium is assumed to be transpired in the same concentration as its concentration in the groundwater (Negri 2001). The phytoremediation system was designed so that in a few years, the rate of transpiration of water will match the natural recharge to the aquifer. This will essentially stop the movement of the contamination plume (Quinn et al. 2001). Work on phytoremediation has continued at Argonne National Laboratory, with an anticipated operating period of 20 years. Initial results showed a $73 \%$ reduction in groundwater tritium concentration over a 2.8 year time period. A report is available covering interim results (EPA 2003).

Purpose of the tritium phytoremediation project at the Savannah River Site is to reduce the volume of water reaching contaminated aquifers and reduce the volume of contaminated water reaching surface water sources. Reduction of recharge and removal of water via the plant roots increases the time for decay of the tritium while it is still in the ground. Although this results in tritiated water being transpired into the atmosphere, this remediation method is considered acceptable at the Savannah River Site because of the distance to the nearest population center (Sullivan 2001, Blount et al. 2003). The potential maximum exposed individual off site dose from a liquid release of $1200 \mathrm{Ci}$ of tritium to the Savannah River is twice the dose for an airborne release of $1200 \mathrm{Ci}$ of tritium $(0.0060 \mathrm{mrem}$ vs $0.0027 \mathrm{mrem})$. The total liquid-pathway 
population dose of 0.20 person-mrem is essentially the same as the airborne-pathway population dose (Blount et al. 2003).

A sheet pile dam for collection of water and forest irrigation system was installed in 2000 and 2001 , respectively, for tritium remediation at a cost of about $\$ 1,500,000$. Tritiated water behind the dam is used for irrigation of 25 acres of natural forest pines and hardwood trees located up gradient of the seep line. The irrigation supplements natural precipitation. Annual operating cost is about $\$ 500,000$ and about 7,570,000 liters $(2,000,000$ gallons) of tritiated water was used for irrigation of the forest in FY 2003 (Blount 2003). This project has resulted in a 65\% reduction in tritium concentrations in water discharged to Fourmile Branch (SRS 2008).

\subsubsection{Incineration}

Incineration or direct contact evaporation provides a controlled and measurable means of disposing of tritiated water though a stack. The Brookhaven National Laboratory used a low flow pumping system to remove the highest concentrations of tritium from the aquifer south of the High Flux Beam Reactor. Approximately 340,000 liters (90,000 gallons) of tritiated water at $500,000 \rho \mathrm{Ci} / \mathrm{L}$ was transported to Oakridge National Laboratory for disposal at the GTS Duratek incinerator. Transportation and off site disposal cost of the tritiated groundwater was about $\$ 5.30$ per liter (\$20 per gallon). Low flow pumping, transportation, and incineration were stopped in early 2001 after removing the target $0.2 \mathrm{Ci}$ of tritium from the aquifer. The DOE at Brookhaven made the decision to dispose of the tritiated groundwater offsite rather than construct and operate a treatment facility at Brookhaven (ROD 2000, Klem 2004).

\subsubsection{Application at the Hanford Site}

Evaporation has the advantage that it may completely eliminate the liquid tritium waste stream, often at a moderate cost compared to separations options. A major negative is that it discharges the tritium into the air.

Table 5 shows the maximum tritium concentration and depth to groundwater. Depths range between $20 \mathrm{~m}$ and $100 \mathrm{~m}$ except at the Columbia River shoreline. Also, phytoremediation for minimizing water entering a contaminated aquifer typically uses either hybrid poplars or pine trees. Neither of these types of plants would be amenable to the natural environment on the Hanford site. The 1994 tritium technology evaluation scored irrigation (phytoremediation) as the poorest based on relative cost and risk (Allen 1994). 
DOE/RL-2009-18

Revision 0

Table 5. Maximum Tritium Concentrations and Depth to Water at Hanford ${ }^{1}$

\begin{tabular}{|c|c|c|c|}
\hline \multirow{2}{*}{ Area } & \multicolumn{2}{|c|}{$\begin{array}{c}\text { Maximum Tritium } \\
\text { concentration, } \rho \mathrm{Ci} / \mathrm{L}\end{array}$} & \multirow{2}{*}{$\begin{array}{c}\text { Depth to } \\
\text { Water, } \mathrm{m}\end{array}$} \\
\cline { 2 - 4 } & Well & Shoreline & \\
\hline $100 \mathrm{~B} / \mathrm{C}$ & $\mathbf{1 2 5 , 0 0 0}$ & 19,200 & $<1$ to 30 \\
\hline $100 \mathrm{D}$ & $\mathbf{3 2 , 5 0 0}$ & 10,900 & $<1$ to 25 \\
\hline $100 \mathrm{H}$ & 6,030 & - & $<1$ to 12 \\
\hline $100 \mathrm{~F}$ & 19,800 & - & $<1$ to 14 \\
\hline $100 \mathrm{~K}$ & $\mathbf{6 6 9 , 0 0 0}$ & 4,750 & $<1$ to 22 \\
\hline $100 \mathrm{~N}$ & $\mathbf{2 6 , 5 0 0}$ & 7,800 & $>1$ to 21 \\
\hline $200 \mathrm{ZP}$ & $\mathbf{1 , 8 2 0 , 0 0 0}$ & - & 50 to 100 \\
\hline $200 \mathrm{UP}$ & $\mathbf{1 , 0 2 0 , 0 0 0}$ & - & 65 to 100 \\
\hline $200 \mathrm{BP}$ & $\mathbf{9 5 , 5 0 0}$ & - & 45 to 50 \\
\hline $200 \mathrm{PO}$ & $\mathbf{5 7 1 , 0 0 0}$ & 3,790 & - \\
\hline $300 \mathrm{FF}-5$ & $\mathbf{1 , 4 7 0 , 0 0 0}$ & 7,730 & $<1$ to 18 \\
\hline 1100 & 258 & - & 2 to 30 \\
\hline
\end{tabular}

Notes: 1) Source of information is Hartman (2006). Concentrations in bold type exceed the drinking water standard (MCL) of $20,000 \rho \mathrm{Ci} / \mathrm{L}(0.020 \mu \mathrm{Ci} / \mathrm{L})$.

\subsection{RELATIVE COST OF MITIGATION OPTIONS}

Costs for options to mitigate tritium in Hanford waste water will vary substantially depending on the technical process option selected. Costs can also be expected to vary substantially depending on site specific and project specific factors. Available cost estimate information for various technologies is identified in the sections that discuss those technologies. In most cases the available cost data was not developed for specific Hanford wastewater treatment scenarios. However, the available data provides some insight into the rough order of magnitude costs.

To develop more accurate cost estimates, engineering studies would need to be performed to estimate equipment size, energy demand, and capital cost and operating costs. In addition, specific scenarios would need to be defined, including wastes to be treated or otherwise mitigated, location, capacity, operating duration, applicable state and federal requirements for treated wastewater and concentrated product, etc. Despite these limitations, some general comments on relative costs can be made, as discussed below and summarized in Table 6 . 
- Separation is typically the most expensive overall mitigation option. For a large baseload type facility operated almost continuously, sized to treat the full stream currently discharged to the SALDS, and designed to reduce tritium content below the drinking water standard, the total treatment cost (capital, operation, utilities, and other project costs) is expected to be in the range of dollars per gallon, likely at least several dollars per gallon. The water distillation, CECE, Bithermal Hydrogen-Water, and Girdler Sulfide Processes all appear to be technically viable candidate separation processes. Available information is not sufficient to determine a clear preference or ranking among these tritium separation processes. The preferred option may vary depending on power and steam costs, plant capacity, and base load versus cyclic or campaign type operations and other scenario/site specific factors.

- Energy costs for the treating high volume, low concentration tritium wastewater by conventional separation technologies (distillation, electrolysis, CECE, etc.) have been estimated to range from 50 to $200 \mathrm{MW}$ (Allan 1995). The energy component to the treatment cost would range from $\$ 0.50$ to $\$ 2.00$ per gallon, and the total power requirement would consume 5 to $20 \%$ of the electrical capacity of the Energy Northwest Columbia Generating Station. The high energy consumption is not deemed appropriate for removing a small amount of tritium from Hanford ETF outfall.

- For separations options that produce a concentrated tritium product, options for handling, storage, and disposal will also significantly affect total cost.

- Cost estimates prepared to support selection of the current SALDS option suggest that the cost for mechanical evaporation will be on the order of tenths of a dollar per gallon, while costs for ground discharge and extended delay in slow moving groundwater (current SALDS approach) are estimated to be less than $\$ 0.01$ per gallon (Lueck 2009). These estimates were based on the assumption that the full stream currently discharged to SALDS would be treated.

- The cost for all mitigation options will tend to increase in terms of dollars per gallon for smaller processing capacity and intermittent operation.

- Costs for water treatment at existing Hanford site pump and treat projects provide additional perspective on typical wastewater treatment costs. Hanford 100 Area projects and contaminants removed are as follows: 100-HR-3, hexavalent chromium; 100-KR-4, hexavalent chromium; and 100-NR-2, Strontium-90. Fully burdened treatment costs for these projects averaged about $\$ 0.05$ per gallon for the six years ended in 2002 (see Section 5.0 of Kelty et al. 2003). Hanford 200 Area projects and contaminants removed are as follows: 200-UP-1, uranium, technicium 99, carbon tetrachloride, and nitrate; and, 200-ZP-1, carbon tetrachloride. Fully burdened treatment costs for these projects averaged less than $\$ 0.03$ per gallon for the six years ended in 2002 (see Section 4.0 of Erb et al. 2003). 
Table 6. Comparison of Mitigation Approaches

\begin{tabular}{|c|c|c|c|c|}
\hline $\begin{array}{l}\text { Mitigation } \\
\text { Approach }\end{array}$ & $\begin{array}{c}\text { Typical } \\
\text { Implementation or } \\
\text { Technology }\end{array}$ & Efficiency & Cost Information & Comments \\
\hline $\begin{array}{l}\text { Separation } \\
\text { treatment }\end{array}$ & $\begin{array}{l}\text { Water Distillation, } \\
\text { CECE, bithermal } \\
\text { hydrogen, GS }\end{array}$ & $\begin{array}{l}\text { Efficiencies to meet } \\
\text { drinking water } \\
\text { standard demonstrated } \\
\text { for CECE, expected } \\
\text { achievable by others } \\
\text { with sufficient staging }\end{array}$ & $\begin{array}{l}\text { For large base load type } \\
\text { facility costs expected to be in } \\
\text { dollars per gallon range. } \\
\text { Increased by smaller size, } \\
\text { intermittent operation, or short } \\
\text { operating life }\end{array}$ & $\begin{array}{l}\text { Handling and } \\
\text { disposal of } \\
\text { concentrated tritium } \\
\text { stream will add } \\
\text { additional costs }\end{array}$ \\
\hline Decay & $\begin{array}{l}\text { Discharge to slow } \\
\text { moving ground } \\
\text { water via Crib or } \\
\text { percolation pond }\end{array}$ & $\begin{array}{l}\text { Efficiency determined } \\
\text { by travel time to } \\
\text { release point. Models } \\
\text { predict acceptable } \\
\text { efficiency for SALDS }\end{array}$ & $\begin{array}{l}\text { For large volume operated } \\
\text { over a long period of time } \\
\text { (such as SALDS) cost } \\
\text { expected to be in cents per } \\
\text { gallon range }\end{array}$ & $\begin{array}{l}\text { Current SALDS } \\
\text { approach }\end{array}$ \\
\hline Decay & $\begin{array}{l}\text { Upgradient } \\
\text { pumping, barriers, } \\
\text { or reduced inflow } \\
\text { to delay release }\end{array}$ & $\begin{array}{l}\text { Site specific and } \\
\text { highly variable }\end{array}$ & $\begin{array}{l}\text { Costs are site specific and } \\
\text { highly variable. Massive } \\
\text { barriers to control ground } \\
\text { water movement at Hanford } \\
\text { judged economically } \\
\text { infeasible }\end{array}$ & $\begin{array}{l}\text { Does not appear } \\
\text { applicable to } \\
\text { Hanford due to large } \\
\text { areas and large } \\
\text { perimeter }\end{array}$ \\
\hline $\begin{array}{l}\text { Mechanical } \\
\text { evaporation }\end{array}$ & Boiler, incinerator & $\begin{array}{l}100 \% \text { of tritiated } \\
\text { water can be } \\
\text { evaporated }\end{array}$ & $\begin{array}{l}\text { For large volume base load } \\
\text { type facility cost is expected to } \\
\text { be in tenths of a dollar per } \\
\text { gallon range. Expected to be } \\
\text { much higher for small } \\
\text { volumes }\end{array}$ & $\begin{array}{l}\text { Results in } \\
\text { atmospheric } \\
\text { discharge. Rated } \\
\text { very poorly in initial } \\
\text { option evaluations }\end{array}$ \\
\hline $\begin{array}{l}\text { "Natural" } \\
\text { evaporation }\end{array}$ & $\begin{array}{l}\text { Solar evaporation, } \\
\text { evaporation by } \\
\text { plants, irrigation }\end{array}$ & $\begin{array}{l}\text { Solar evaporation } \\
\text { could evaporate } \\
\text { essentially } 100 \% \text {, } \\
\text { others highly variable }\end{array}$ & $\begin{array}{l}\text { Costs are site specific and } \\
\text { highly variable }\end{array}$ & $\begin{array}{l}\text { Results in } \\
\text { atmospheric } \\
\text { discharge. Rated } \\
\text { very poorly in initial } \\
\text { option evaluations }\end{array}$ \\
\hline
\end{tabular}


- Costs for options such as pumping, underground barriers, and phytoremediation may be relatively low in terms of dollars per gallon, but are highly project specific. These options do not appear to be applicable to the Hanford wastewater treatment application.

- For mitigation of relatively small volumes, such as treatment or relocation of a relatively small-volume high-concentration wastes, mitigation process costs (equipment, and operation) are likely to be overshadowed by other project costs such as waste characterization, engineering, technology development/definition, safety evaluations and approvals, permitting, and overheads.

- For waste water that is already in the ground, it appears obvious that decay in place is the lowest cost option for tritium mitigation. For wastewater discharged from the ETF, continued discharge to ground water via the SALDS is undoubtedly the lowest cost mitigation option. The tritium concentration in groundwater will gradually drop due to radioactive decay and dilution. For the contamination levels in SALDS discharge and in groundwater identified at Hanford, decay alone will reduce tritium concentrations below the drinking water standard in less than 100 years. 


\subsection{REFERENCES}

40 CFR 141.16, "National Primary Drinking Water Regulations," Code of Federal Regulations, Title 40, Part 141.

Alekseev, I. A., S. D. Bondarenko, O. A. Fedochenko, T. V. Vasyanina, K. A. Konoplev, E. A. Arkhipov, T. V. Vofonina, A. I. Grushko, A. S. Tchijov, and V. V. Uborsky, 2003, Heavy Water Detritiation by Combined Catalytic Exchange at the Experimental Industrial Plant, Fusion Engineering and Design, Vol. 69 pp33-37.

Alekseev, I. A., S. D. Bondarenko, O. A. Fedochenko, A. I. Grushko, S. P. Karpov, K. A. Konoplev, E, A. Arkhipov, T. V. Vasyanina, T. V. Voronona, 2002, The CECE Experimental Industrial Plant for Reprocessing of Tritiated Water Wastes, Fusion Science and Technology, Vol. 41 pp1097-1101.

Alekseev, I. A., S. D. Bondarenko, O. A. Fedochenko, T. V. Vasyanina, K. A. Konoplev, E. A. Arkhipov, 2007, Improvement of PNPI Experimental Industrial Plant based on CECE Process for Heavy Water Detritiation, "Presentation to $8^{\text {th }}$ International Conference on Tritium Science and Technology, Rochester NY.

Allen, W. L., 1994, Tritiated Wastewater Treatment and Disposal Evaluation for 1994, DOE/RL-94-77, Westinghouse Hanford Company for U.S. Department of Energy, Richland Operations Office, Richland, Washington.

Allen, W. L., 1995, Tritiated Wastewater Treatment and Disposal Evaluation for 1995 , DOE/RL-95-68, Westinghouse Hanford Company for U.S. Department of Energy, Richland Operations Office, Richland, Washington.

Andreev, B.M. 2007, Magomedbekov, E.P., Raitman, A.A., Pozenkevich, M.B., Sakharovsky, Yu.A., Khoroshilov, A.V., Separation of Isotopes of Biogenic Elements in Two-Phase Systems, Elsevier, Amsterdam, The Netherlands.

Antoniazzi, A. B., F. E. Bartoszek, and A. M. Sherlock, 2006, The use of Cryogenically Cooled 5 A Molecular Sieves for Large Volume Reduction of Tritiated Hydrogen Gas, Paper presented at Waste Management 2006, Tucson AZ.

Barnett, D. B., M. P. Bergeron, C. R. Cole, M. D. Freshley, and S. K. Wurstner, 1997, Tritium Monitoring in Groundwater and Evaluation of Model Predictions for the Hanford Site 200 Area Effluent Treatment Facility, PNNL-11665, Pacific Northwest National Laboratory, Richland, Washington.

Barnett, D. B., J. T. Reiger and E. C. Thornton, 2003, PNNL-14449, Results of Tritium Tracking and Groundwater Monitoring at the Hanford Site 200 Area State-Approved Land Disposal Site-Fiscal Year 2003, Pacific Northwest National Laboratory, Richland, Washington. 
Bisping, L. 2008, PNNL-17603, App. 1, Hanford Site Environmental Surveillance Data Report for Calendar Year 2007, Pacific Northwest National Laboratory, Richland, Washington.

Blount, G .C., C. C. Caldwell, J. E. Cardoso-Neto, K. R. Conner, G. T. Jannik, C. E. Murphy Jr., D. C. Noffsinger, and J. A. Ross, 2003, "The Use of Natural Systems to Remediate Groundwater; Department of Energy Experience at the Savannah River Site", Federal Facilities Environmental Journal, p 55-73, Spring 2003

Blount, G. C., 2003, Telephone conversations with M. J. Klem on November 21, 2003 and December 15, 2003, Westinghouse Savannah River, Aiken, South Carolina.

BNL 2002a, “Tritium System Finishes Job 'Low Flow' Pumping Continues” CleanUp Updates, Vol 6, No 1 Brookhaven National Laboratory, Upton, New York

BNL 2002b, 2002 Site Environmental Report, Brookhaven National Laboratory, Upton, New York.

BNL 2007, Department of Energy, EPA, and N. Y. State Agree on Brookhaven Lab Remediation Projects, News Release Number 07-X07, May 16, 2007, Brookhaven National Laboratory, Upton NY.

BNL 2008, Groundwater, Brookhaven National Laboratory Community Relations Website, Brookhaven National Laboratory, Upton NY.

Bonnett, I., Busigin A., Shapiro A., 2008A, "Tritium Removal and Separation Technology Developments", Fusion Science and Technology, 2008, Vol.54, pp. 209-214

Bonnett, I. 2008B, Telephone conversation with G. Stegen on December 18, 2008, GE Hitachi Nuclear Energy Canada, Inc., Petersborough, Ontario

Brown, M. J. 1993, Project C-018H Waste Water Engineering Alternatives Report Supplementary Information on Treated Effluent Disposal Site Engineered Structures, WHC-SD-C0189-ER-003, Rev 0A, Westinghouse Hanford Company, Richland, Washington

Caron, M.E., 2008, Results of Tritium Tracking and Groundwater Monitoring at the Hanford Site 200 Area State-Approved Land Disposal Site, SGW-38802, Rev. 0, CH2M-HILL Plateau Remediation Company

Cristescu, I., U. Tamm, Ioana-R. Cristescu, M. Glugla, C. J. Caldwell-Nichols, 2002, "Investigation of Simultaneous Tritium and Deuterium transfer in a Catalytic Isotope Exchange Column for Water Detritiation", Fusion Engineering and Design, Vol. 61-62 pp 537-542.

Cristescu, I., U. Tamm, Ioana-R. Cristescu, U. Tamm, C. J. Caldwell-Nichols, M. Glugla, D. Murdoch, S. Welte, 2003, Simultaneous Tritium and Deuterium transfer in a Water Detritiation CECE facility at TLK", Fusion Engineering and Design, Vol. 69, pp 109113,2003 
Cristescu, I., U. Tamm, Ioana-R. Cristescu, L. Dörr, M. Glugla, D. Murdoch, S. Welte, 2006, "Long Term Performances assessment of water detritiation system components", Fusion Engineering and Design, Vol. 81, pp 839-844, 2006

Cristescu, I., U. et. al., 2008, Experiments on Water Detritiation and Cryogenic Distillation at TLK; Impact on ITER Fuel Cycle Subsystems Interfaces, Fusion Science and Technology, Vol 54 pp 440-445.

Diabate, S. and Strack, S. 1993, "Organically Bound Tritium - Tritium Transport and Cycling in the Environment”, Health Physics Vol 45, No 6, pp 698- 712.

Drake, R.H. 1996, "Recovery of Tritium from Tritiated Waste Water Cost-Effectiveness Analysis”, LA-UR-97-3767, Los Alamos National Laboratory, June 1996

DOE Order 5400.5, Radiation Protection of the Public and the Environment.

Dorsch, W. R., et. a1., 2007, Groundwater Remediation Program at Brookhaven National Laboratory, Upton New York, Fourteenth Conference on the Geology of Long Island and Metropolitan New York, SUNY at Stony Brook

Ecology 2000, State Waste Discharge Permit ST-4500, Washington State Department of Ecology, Kennewick, Washington.

Ecology, EPA, and DOE, 2007, Hanford Federal Facility Agreement and Consent Order, 2 vols., Washington State Department of Ecology, U.S. Environmental Protection Agency, and U.S. Department of Energy, Olympia, Washington.

Ellis, R. E., J. E. Lentz, M. L. Rogers, and C. J. Sienkiewicz, 1982, Final Report: Development of Combined Electrolysis Catalytic Exchange, MLM-2952, Monsanto Research Corp., Miamisburg, Ohio.

EPRI, 2002, Evaluation of Low Level Waste Technology- “A Media Based Tritium Removal Process, " Final Report, 1006710, Electric Power Research Institute 3412 Hillview Ave. Palo Alto, California 94304.

EPA, 2003, Deployment of Phytotechnology in the 317/319 Area at Argonne National Laboratory-East, EPA/540/R-05/011, U. S. Environmental Protection Agency, Cincinnati Ohio.

Erb, D.B., R. S. Edrington, G.G. Kelty, R. F. Raidl, and W.J. McMahon, 2003, Fiscal Year 2002 Annual Summary Report for 200-UP-1 and 200-ZP-1 Pump-and-Treat Operations, DOE/RL-2002-67, Rev. 0., United States Department of Energy, Richland, Washington.

Fedorchenko, O. A., I. A. Aleksdev, and V. D. Trenin, 2001, “A New Type Separation Column for the Water-Hydrogen Isotope Catalytic Exchange Process", Fusion Engineering and Design, Vol. 58-59 pp 433-438. 
Fedorchenko, O. A., et. al., 2005, Modeling of the Process of Three-Isotope H, D, T Exchange Between Hydrogen Gas and Water Vapor on Pt-SDBC Catalyst over a Wide Range of Deuterium Concentration, Fusion Science and Technology, Vol 48 No. 1, pp 120-123.

Fedorchenko, O. A., et. al., 2007, Water-Hydrogen Isotope Exchange Process Analysis, Presentation to $8^{\text {th }}$ International Conference on Tritium Science and Technology, Rochester NY.

Field, J. G., 1991, C-108 Treated Effluent Disposal Alternatives Engineering Study, WHC-SDC018H-ES-002 Rev 0, Westinghouse Hanford Company, Richland, Washington.

Flach, G. P., 2002, Evaluation of Evaporation Technologies for Treating Contaminated Groundwater, WSRC-TR-2002-00432, Rev 0, Westinghouse Savannah River Company, Aiken, South Carolina.

Fulbright, H. H., A. L. Schwirian-Spann, K. M. Jerome, B. B. Looney, and V. Van Brunt, 1997, Status and Practicality of Detritiation and Tritium Reduction Strategies for Environmental Remediation, WSRC-RP-96-0075, Rev 0, Westinghouse Savannah River Company, Aiken, South Carolina.

Graham, W. R. C., A. E. Everett, J. R. R. Tremblay, J. M. Miller, and D. A. Spagnolo, 2002, Demonstration of Very High Detritiation Factors with a Pilot-Scale CECE Facility, Fusion Science and Technology, Vol. 41 pp 1137-1141.

Hammerli, M., W. H. Stevens, and J. P. Butler, "Combined Electrolysis and Catalytic Exchange (CECE) Process for Hydrogen Isotope Separation," Proceedings for the Symposium on Separation of Hydrogen Isotopes, ACS Symposium Series 68, Washington, D. C. (1978)

Hartman, M. J., 2003, Hanford Site Groundwater Monitoring for Fiscal Year 2002, PNNL-14187, Pacific Northwest National Laboratory, Richland, Washington.

Hartman, M. J., 2007, Hanford Site Groundwater Monitoring for Fiscal Year 2007, PNNL-16346, Pacific Northwest National Laboratory, Richland, Washington.

Heiser, J. H., M. North-Abbot, T Sullivan, H. Ludewig, K Manchester. M. Zaluski, G. Penny and J. Bower, 2002, Viscous Liquid Barrier Demonstration at the Brookhaven National Laboratory LINAC Isotope Producer, BNL-67336, Brookhaven National Laboratory, Upton, New York.

Heinze, S., P. Bussiere, and Th. Pelletier, 2003, "French Experience in Tritiated Water Treatment”, Fusion Engineering and Design, Vol. 69 pp 67-70, 2003

Heung, H. K., et. al., 2007, Method to Test Isotopic Separation Efficiency of Palladium Packed Columns, Presentation to $8^{\text {th }}$ International Conference on Tritium Science and Technology, Rochester NY. 
HST, 1991, RL-MW023, Technology Need/Opportunities Statement, DOE/RL-98-01, Rev. 1, Hanford Science and Technology for the U.S. Department of Energy, Richland Operations Office, Richland, Washington.

Isomura, S., K. Suzuki, and M. Shibuya, 1988, Separation and Recovery of Tritium by Hydrogen Water Isotopic Exchange Reaction, Fusion Technology, Vol. 14, p 518-523, September 1988.

ITER, 2008, Support for Development of Water Detritiation Systems Technical Specification for Tenders, ITER IO, Cadarache France

Iwai, et. al., 2002, The Water Detritiation System of the ITER Tritium Plant, Fusion Science and Technology, Vol. 41 pp 1126-1130.

Jeppson, D. W., G. Collins*, L. Furlong* and S. L. Stocker*, 2000, Separation of Tritium from Wastewater, HNF-4906-FP, Rev 0, COGEMA Engineering Corporation, Richland, Washington, *Molecular Separation Inc, Sarasota, FL.

Jeppson, D. W.,1999, 1999 Evaluation of Tritium Removal and Mitigation Technologies for Wastewater Treatment, DOE/RL-99-42, Rev 0, COGEMA Engineering Corporation for U.S. Department of Energy Richland Operations Office, Richland, Washington.

Jeppson, D. W., R. K. Biyani, and J. B. Duncan 1997, 1997 Evaluation of Technologies for Removal and Mitigation of Tritium for Hanford Site Waste Waters, DOE/RL-97-54 Rev 0, COGEMA Engineering Corporation for U. S. Department of Energy, Richland Operations Office, Richland, Washington.

Kelty, G.G., and R. F. Raidl, 2003, Calendar Year 2002 Annual Summary Report for the 100HR-3, 100-KR-4, and 100-NR-2 Operable Unit Pump-and-Treat Operations, DOE/RL2003-09, Rev. 0, United States Department of Energy, Richland, Washington.

Kinoshita, M. “Computer-Aided Simulation Procedure for Water Distillation Columns”, Journal of Nuclear Science and Technology, Vol. 21(4), pp. 299-307, April 1964

Klem, M. J. and G. E. Stegen, 2004, 2004 Evaluation of Tritium Removal and Mitigation Technologies for Wastewater Treatment, DOE/RL-2004-11, Rev 0, COGEMA Engineering Corporation for U.S. Department of Energy Richland Operations Office, Richland, Washington.

Lasser, R., N. Bekris, A. C. Bell, C. Caldwell-Nichols, I. Cristescu, S. Ciattaglia, P. Coad, Ch. Day, M. Glugla, J. Likonen, D. K. Murdoch, S. Rosanvallon, and F. Scaffidi-Argentina, 2003, Tritium Related Studies at the JET Facilities, Fusion Engineering and Design, Volume 69.

Lueck, K. J., 2009, email to D. J. Geniesse, ETF Processing Costs, Waste \& Fuels Management Project, February 10, 2009. 
Miller, A. I., 1999, Tritium Treatment Technologies for Groundwater Remediation at Savannah River Site, WSRC-OS-98-00127, prepared by Chalk River Laboratories and Atomic Energy of Canada, Limited, for Westinghouse Savannah River Company, Aiken, South Carolina.

Miller, A. I., 2001 email to D. L. Penwell, Reply to Questions Regarding Tritium Removal Technologies., Atomic Energy of Canada, Limited, March 7, 2001

Miller, A. M., S. L. Celovsky, A. E. Everatt, W. R. C. Graham, and J. R. R. Tremblay, 2002, Design and Operational Experience with a Pilot-Scale CECE Detritiation Process, Fusion Science and Technology Vol. 41 pp1077-1081.

Michling, R., I. Cristescu, L. Dorr, T. Fanghanel, S. Welte, and W. Wurster, 2008, Behaviour of Solid Polymer Membrane Eletrolyzers in Use with Highly Tritiated Water, Fusion Science and Technology, Vol 54 pp 470-474.

Neitzel, D.A. 2004, Hanford Site National Environmental Policy Act (NEPA) Characterization, PNNL-6415, Rev. 17, September 2005, Pacific Northwest National Laboratory, Richland, Washington.

Negri, M. C., 2001, email to D. L. Penwell, Reply for Questions Regarding Phytoremediation and Tritium, Argonne National Laboratory, April 18, 2001.

North-Abbot, M., 2004, Viscous Liquid Barrier Costs, MSE Technologies Applications Inc., Butte, MT, January 6, 2004.

Ogata, Y., et. al., 2003, Tritium Separation from Heavy Water by Electrolysis with Solid Polymer Electrolyte, Journal of Radioanalytical and Nuclear Chemistry, Vol. 255, No. 3 pp539541.

Ogata, Y., et. al., 2005, Tritium Separation by Electrolysis using Solid Polymer Electrolyte, Fusion Science and Technology, Vol 48 No. 1, pp 136-139.

Ortiz, D. J. 2003, Telephone conversation with M. J. Klem, December 4, 2003, U. S. Department of Energy Richland Operations, Richland, Washington.

Penwell, D. L., 2001, 2001 Evaluation of Tritium Removal and Mitigation Technologies for Waste Water Treatment, DOE/RL-2001-33, Rev 0, COGEMA Engineering Corporation for U. S. Department of Energy, Richland Operations Office, Richland, Washington.

Perevezentsev, A., B. M. Andreev, E. P. Magomedbekov, Yu. S. Pak, M. B. Rozenkevich, Yu. A. Sakharovskii, 2002, Difference Between HETP and HTU for Isotopic Mixtures of Protium-Tritium and Protium-Deuterium in Isotopic Exchanges Between Water and Hydrogen on Hydrophobic Catalyst, Fusion Science and Technology Vol. 41 pp $1107-$ 1111. 
Perevezentsev, A. N., A. C. Bell, P. D. Brennan, and J. L. Hemmerich, 2002, Development of a Water Detritiation Facility for JET, Fusion Engineering and Design Vol 61-62 pp585589.

Perevezentsev, A. N. and A. C. Bell, 2008, Development of Water Detritiation Facility for JET, Fusion Science and Technology Vol 53 No. 3, pp816-829.

Quinn, J. J., M. C. Negri, R. R. Hinchman, L. P. Moos, J. B.Wozmiak, (Argonne National Laboratory), and E. G. Gatliff, (Applied Natural Sciences), 2001, Predicting the Effect of Deep-Rooted Hybrid Poplars on the Groundwater Flow System at a Large-Scale Phytoremediation Site, International Journal of Phytoremediation, Vol. 3., No. 1., p. 41-60, 2001.

Roblyer, S.P., "Plutonium and Tritium Produced in the Hanford Site Production Reactors", WHC-SD-CP-RPT-014, Westinghouse Hanford Company, Richland Washington

ROD 2000, Operable Unit III Record of Decision, Brookhaven National Laboratory, April 14, 2000, Upton, New York.

RL, 1999, Fiscal Year 1999 Waste Tank Science Need, RL-WT047-S, U.S. Department of Energy, Richland Operations Office, Richland, Washington.

Schnelle, M. A., J. R. Feucht and J. E. Klett, 1989, "Root System of Trees-Facts and Fallacies", Journal of Arboriculture Vol 15, No 9 pp 201-205.

Shmayda, C. R., et. al., 2007, Operation of a $2.6 \mathrm{Mg} /$ year Heavy Water Detritiation Plant, Presentation to $8^{\text {th }}$ International Conference on Tritium Science and Technology, Rochester NY

Sessions, K. L., 2005, Processing Tritiated Water at the Savannah River Site: A Production Scale Demonstration of a Palladium Membrane Reactor, Fusion Science and Technology, Vol 48 No. 1, pp 91-97.

Sienkiewicz, C. J., and J. E. Lentz, 1988, "Recovery of Tritium from Water," Fusion Technology, Vol. 14, pp 444-449, 1988.

Son, S. H., et. al., 2007, Tritium Removal and Applications for Wolsong Heavy Water Reactions, Presentation to $8^{\text {th }}$ International Conference on Tritium Science and Technology, Rochester NY

SRS 2008, Soil and Groundwater Closure Projects Accomplishments 2007, srs.gov/general/pubs/ERsum/er08/07erpdfs/sgcp07.pdf, US Department of Energy, Savannah River Site,

Staack, G. C., 2008, Examination of 80 C Desorption Isotherms of Tritium Aged Pd/k and $L A N A .75$, Fusion Science and Technology, Vol 54 No. 1, pp 85-88. 
Sullivan, T., 2001, Letter to G. Penny, Minutes of the Conference Call on Tritium Treatment Technologies, Brookhaven National Laboratory, January 30, 2001

Sullivan, T, 2003, Telephone conversation with M. J. Klem, November 18, 2003, Brookhaven National Laboratory, Upton, New York.

Van Hook, A, 1968, "Vapor Pressures of the Isotopic Waters and Ices", Physical Chemistry, Vol. 72, No. 4, pp 1234-1244, 1968

Vasut, F., et. al., 2008, Improvement of Pt/PTFE Catalyst Type Used for Hydrogen Isotope Separation, Fusion Science and Technology, Vol 54 No. 2, pp 437-439.

Willms, R. S., et. al., 1995, Recent Palladium Membrane Reactor Development at the Tritium Systems Test Assembly, Fusion Technology, Vol 28, pp 772-772.

Willms, R. S., and S. A. Birdsell, 1999, Tritium Recovery from Waste Using a Palladium Membrane Reactor, Paper presented at Waste Management 1999, Tucson AZ

Yamanishi, T., et. al., 2008, Recent Results of R\&D Activities on Tritium Technologies for ITER and Fusion Reactors at TPL of JAEA, Fusion Engineering and Design, Vol 83 pp 13591363.

Ying, S, et. al., 2008, "Study on the Technology of CECE-GC System for Water Detritiation", Fusion Engineering and Design, Article in Press, 2008 